\title{
THE EFFECTIVENESS OF THE
} MONETARY TRANSMISSION MECHANISM IN UKRAINE SINCE THE TRANSITION TO INFLATION TARGETING

\section{OLEKSANDR ZHOLUD ${ }^{a}$, VOLODYMYR LEPUSHYNSKYI ${ }^{a}$, SERGIY NIKOLAYCHUK $^{a}$}

${ }^{a}$ National Bank of Ukraine, Kyiv, Ukraine

E-mail: Serhii.Nikolaichuk@bank.gov.ua, corresponding author

\begin{abstract}
This paper analyzes the effectiveness of monetary transmission channels in Ukraine since the National Bank of Ukraine (NBU) transitioned to inflation targeting and after the central bank established its new approach to monetary policy implementation. The authors conclude that the central bank has sufficient control over short-term interest rates in the interbank market and that it uses them to influence other financial market indicators. At the same time, further transmission via the interest rate channel is constrained by weak lending and the banking system's slow post-crisis recovery. The exchange rate channel remains the most powerful avenue of monetary transmission. After the NBU switched to a floating exchange rate and an active interest rate policy, its key rate became a means of influencing exchange rates. The exchange rate channel's leading role is expected to gradually decrease but remain important, as is typical for small open economies.
\end{abstract}

JEL Codes

E31, E42, E52, E58, O11

Keywords

monetary transmission mechanism, monetary policy, interest rate channel, exchange rate channel, expectations channel

\section{INTRODUCTION}

A central bank's key rate has traditionally been the most important instrument of its monetary policy. The central bank uses it to affect the economy, especially to achieve inflation targets. The process of transmitting a signal from the key rate to other interest rates and, in the end, to investment, consumption, and savings decisions is called the "transmission mechanism".

Numerous empirical studies for both developed and developing economies show that the transmission process takes different amounts of time and its effects differ greatly in different countries and in different periods. Bernanke and Gertler (1995) say the monetary transmission is like a black box where the mechanism of step-by-step signal transmission remains hidden and an observer can see only the initial change and the outcome.

The monetary transmission mechanism (MTM) is difficult to study, at least partly because of other factors that affect macroeconomic processes and the endogeneity problem. A central bank's policy represents a response to external challenges and economic agents take into account not only the current policy but also expected actions. For instance, if a change in the key rate is expected to be temporary, banks often opt to not revise interest rates for long-term loans and deposits (e.g., Andries \& Billon, 2016). In addition, the response is often asymmetrical; loan rates typically react slower and to a lesser degree to a lowering of the key rate than to an equal rate increase.

In Ukraine, determining the quantitative power of MTM channels is even more difficult owing to the significant structural and institutional transformation of the economy, including changes in the goals and instruments of monetary policy. These changes reflect the way the central bank influences liquidity and financial markets (the first stage of the MTM) and the way monetary conditions affect the economy and inflation (the second stage of the MTM).

In terms of the first stage, since the NBU established its current approach to monetary policy implementation in 2015-16, the relationship between the NBU's key rate (its key monetary policy instrument) and short-term money market rates has been very strong. This was not the case prior to 2015. Additional impacts on financial market indicators are also clearly visible. 
However, qualitative assessments of further transmission (the second stage) are challenging. The relationships between financial conditions and indicators of the real sector (economic activity and inflation) are weakened by other factors beyond the central bank's control. These include the consequences of the economic and financial crisis and of the banking system's clean-up in 2014-15, changes in fiscal policy, terms of trade, food supply factors, and more.

The exchange rate also plays an important role in monetary transmission, primarily owing to its substantial effect on economic activity, inflationary processes, finances of households, the corporate and public sectors. ${ }^{1}$ This study focuses on both the first transmission stage (the effectiveness of the central bank's influence over exchange rate trends through interest rates and foreign currency interventions) and the second stage (the impact of exchange rates on economic growth and inflation). Both links experienced significant change after the NBU switched from a pegged exchange rate to a floating exchange rate. This study evaluates the effectiveness of monetary transmission channels in Ukraine after the NBU transitioned to inflation targeting, especially through the establishment of a new operational design for monetary policy.

This paper is structured as follows. Section 2 offers an analysis of the key determinants of the MTM in Ukraine, including a description of the latest changes in the NBU's approach to monetary policy and the conditions within which the policy has been executed, with a focus on the characteristics of Ukraine's financial system. Section 3 offers a detailed overview of MTM channels: the interest rate channel, lending channel, exchange rate channel, asset price channel, and expectations channel. This section describes the mechanisms of influence and evaluates the importance of the identified channels. The paper ends with concluding remarks and recommendations on areas of further study.

\section{THE DETERMINING FACTORS OF THE MONETARY TRANSMISSION MECHANISM}

A well-functioning MTM is an important precondition for the successful implementation of inflation targeting. This monetary policy regime allows central banks to effectively perform their key function of ensuring price stability (Masson et al., 1997; Batini et al., 2005; Airaudo et al., 2016).

Like the majority of central banks in developing market economies, the NBU began implementing inflation targeting when the MTM was in its infancy. To a large degree, that is because the NBU's previous currency peg offered no impetus for the development of the MTM and financial markets. Although the NBU's key rate was a de jure "benchmark for the value of money", it de facto had no significant impact on other financial indicators. Therefore, a priority objective during the establishment of inflation targeting was to ensure a design that would enable the NBU to control short-term money market rates.

Further transmission occurs primarily via the banking sector as a central piece of Ukraine's financial system. The slow post-crisis recovery of the banking sector and gradual restoration of financial intermediation have determined, to a substantial degree, the characteristics of Ukraine's MTM. At the same time, the government securities market is growing, as is the NBU's ability to influence the economy by regulating short-term yields.

In general, however, the absence of a developed financial market amid the economic crisis and the banking system's clean-up in 2014-2016 seriously constrained the effectiveness of the transmission mechanism. In addition, the NBU's control over inflationary processes using monetary instruments was hindered by powerful factors over which the central bank had no control, including structural economic reforms, fiscal policy, monopolization of certain markets, a significant dependence on global commodity prices, and others.

\subsection{Operating Framework of Monetary Policy}

After announcing the transition to inflation targeting in 2015, the NBU began to use instruments of interest rate policy. As with most central banks, the NBU's most important instrument is the key rate.

The key rate was de jure established when the NBU was created in 1992. However, the rate was a pure formality as the central bank carried out monetary transactions at discrete interest rates with little dependence on the key rate. The first stage of monetary transmission - the management of short-term interest rates in the interbank market - was de facto absent and the NBU's key rate only played a signaling role.

After changes in the operational design of monetary policy in April 2016, interest rates for the NBU's main liquidity management instruments became tightly pegged to the key rate. $^{2}$ Under conditions of a structural surplus of liquidity, the NBU's market transactions were mostly confined to placing 2-week certificates of deposit at an interest rate equal to the key rate. To dampen short-term interest rate fluctuations in the interbank market, the NBU also carries out overnight transactions at rates pegged to the key rate: the key rate minus 2 p.p. for deposits and the key rate plus 2 p.p. for loans. In addition, the NBU regularly conducts tenders offering refinancing for up to 14 days. ${ }^{3}$

As a result, interest rates in the interbank market are close to the key rate (see Figure 1). Under a liquidity surplus, interbank rates tend to stay closer to the lower part of the range, but they sometimes rise to the upper limit of the range. Money market rates rarely depart the range of interest rates for continuous access instruments (only three times since the beginning of 2016).

Even though the key rate is the decisive factor for shortterm interbank interest rates, other factors also affect their behavior. Up to the end of 2016, interbank interest rates were closer to the key rate, whereas between the start of 2017 and mid-2018, they tended to stay closer to overnight deposit rates. That was caused by the nationalization and recapitalization of PrivatBank, which until the end of 2016

\footnotetext{
${ }^{1}$ Under the inflation targeting regime, the exchange rate is important for countries with developing markets (Nordstrom et al., 2009).

${ }^{2}$ Resolution 277 of 21 April 2016 approving the Regulation on the Principles of Interest Rate Policy of the National Bank of Ukraine

https://bank.gov.ua/document/download?docld=30186366

${ }^{3}$ During 2015-2018: key rate plus 2 pp. Effective 11 January 2019, interest rates on 2-week certificates of deposit and on 2-week refinancing loans are set at the NBU's key rate. https://bank.gov.ua/control/uk/publish/article?art_id=83614488
} 


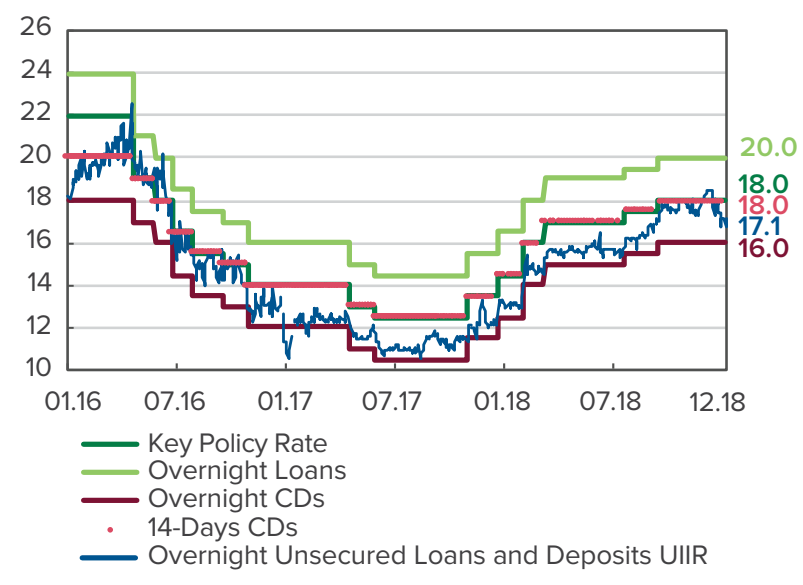

Figure 1. NBU Interest Rates and the Ukrainian Interbank Interest Rate Index, \% p.a. Source: NBU.

had been generating substantial demand for interbank market resources and thus pushing interest rates higher.

More than half of interbank credit market (IBCM) agreements in 2016 were for intermediation services related to financial borrowing by PrivatBank, Ukraine's largest bank by assets. That had a substantial impact on the value of IBCM resources. The reaction of interest rates of its contracts to changes in the NBU's key rate was the longest and the least significant. Since the beginning of 2015, the spread between the cost of PrivatBank's financial borrowings and the average market rate widened gradually to more than 4 p.p. in November 2016.

After PrivatBank was nationalized and halted expensive borrowing, the market's average loan cost has declined by 2 p.p. and the range of interest rate dispersion around the key rate has narrowed significantly (see Figure 2).

Owing to the substantial influence from one large market participant, the study of the deviation of the money market rate from the key rate should be divided into two periods. In the first period (December 2015 - December 2016), the fluctuation of the money market rate was larger and its average value was closer to the key rate (see Table 1).

Table 1. The Central Bank Policy Parameters

\begin{tabular}{l|c|c}
\hline Period & $\begin{array}{c}\text { Average } \\
\text { spread }\end{array}$ & $\begin{array}{c}\text { Standard } \\
\text { deviation }\end{array}$ \\
\hline $2015-12-25^{4} / 2018-12-31$ & 1.131 & 0.78 \\
$2015-12-25 / 2016-12-18^{5}$ & 0.994 & 1.127 \\
\hline $2016-12-18 / 2018-12-31$ & 1.200 & 0.519 \\
\hline
\end{tabular}

Source: Own calculations based on NBU data.

The attenuation of fluctuations and the growth of the average spread size are the result of increasing liquidity (and, probably, of growing trust in the banking system after the PrivatBank nationalization). A large standard deviation means the interbank market rate significantly fluctuates while the key rate remains the same, a sign of periods of liquidity deficit and surplus. A positive spread between the key rate and the money market rate indicates a surplus of freely available funds. At present, this spread should not exceed 2 p.p. - the difference between the key rate and the rate on NBU overnight certificates of deposit. The growth in the average spread after 2016 is a sign of the surplus of liquidity in the system. Liquidity declined beginning in August-September 2018, thus reducing the average spread from its level in 2017 to the first half of 2018.

Other countries, even those with developed financial markets and long-standing monetary policy practices, also see a similar effect from certain factors on the dynamics of short-term interbank interest rates. For instance, after the 2007-2008 crisis in developed economies, some rates that typically moved in unison diverged (i.e., the central bank's key rate and LIBOR, EURIBOR, EONIA, and other interbank rates). The spreads widened as bank counterparties lost confidence in banks and banks were forced to charge a risk premium.

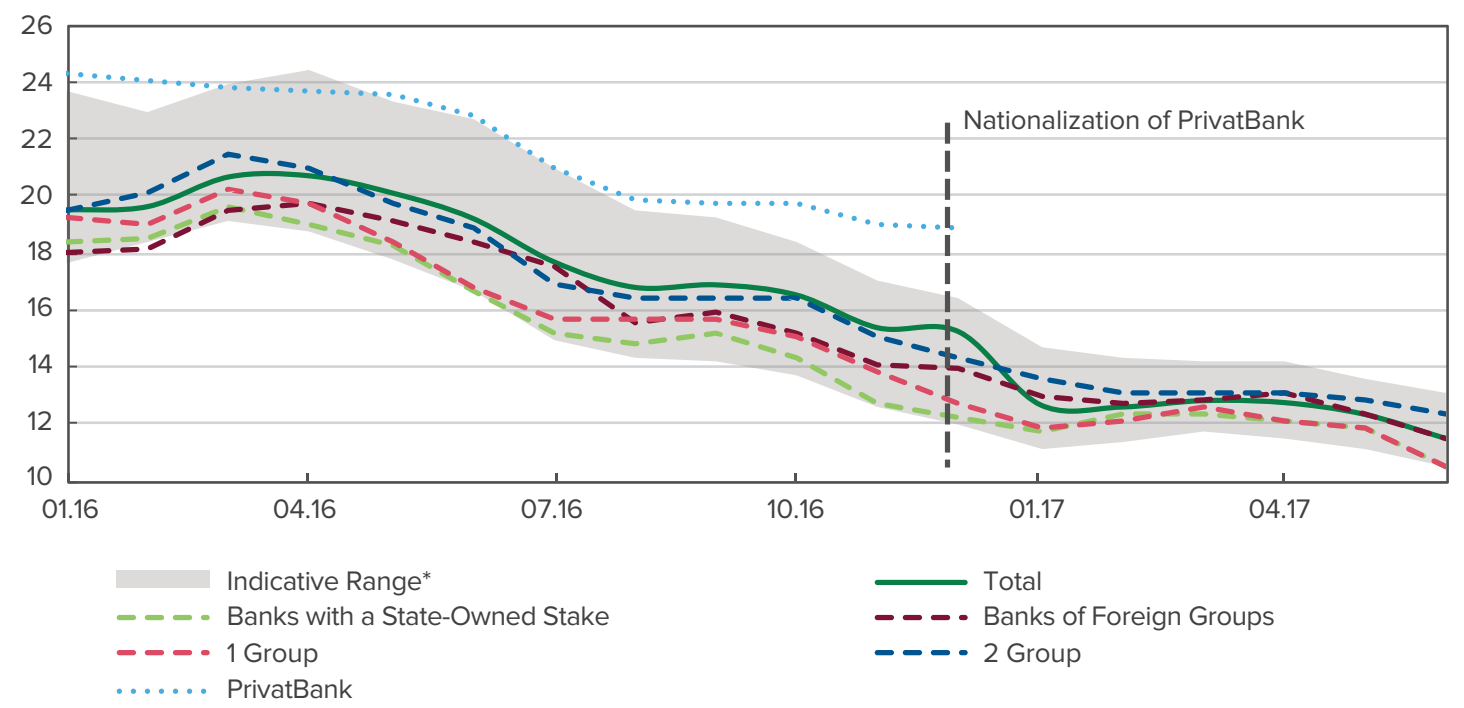

${ }^{*}$ Range of average monthly interest rates on interbank market transactions excluding the highest and lowest $10 \%$.

Figure 2. Loan Interest Rates by Bank Groups, \%. Source: NBU.

\footnotetext{
${ }^{4}$ The date when the Ukrainian Interbank Interest Rate Index was first calculated.

${ }^{5}$ On 18 December 2016, the National Security and Defense Council of Ukraine adopted a resolution on urgent measures to bolster Ukraine's economic security and to protect the interests of depositors, related to the nationalization of PrivatBank.
} 
However, growing uncertainty does not always cause rate spreads to widen. Most banks operating in the interbank money (credit) market have limits on their counterparty banks. Growing uncertainty may result in zero limits (i.e., unavailability of loans) for those counterparties deemed high-risk. In that event, agreements in the money market remain available only to reliable counterparties, for which interest rates are usually lower. A similar situation can sometimes be observed in the Ukrainian interbank market, when agreements between "financially sound" banks (if they have limits on other banks) push interest rates down.

\subsection{The Structure and Characteristics of the Financial System}

The financial system is important from the viewpoint of both stages of the MTM. Firstly, its structure and characteristics define how monetary policy decisions transform into liquidity and prices in the financial market, and secondly, how the latter affect macroeconomic indicators.

Like in many European countries, Ukraine's financial system is bank-centric (as of the end of 2017, bank assets amounted to $84 \%$ of all assets held by financial corporations ${ }^{6}$ ). That domination by banks is the result of a low level of stock market development. Insurance companies make up the bulk of nonbanking financial companies, while private retirement funds, mutual funds, and other structures are almost nonexistent.

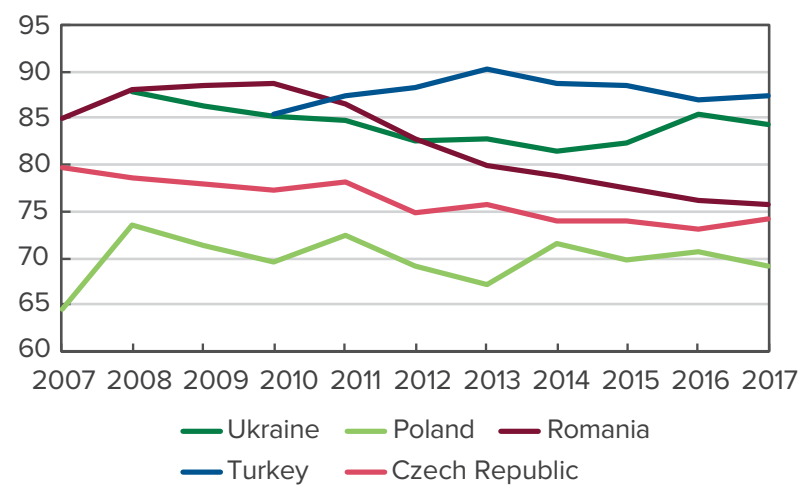

Figure 3. The Banking System's Assets as a Percentage of Financial Assets.

Sources: Central banks of the selected countries, OECD, own calculations.

In Ukraine, markets for stocks, bonds, and some financial derivatives exist on paper, but they are weak. Large Ukrainian companies prefer to issue stocks abroad, both because of the low depth of the local stock market and because of problems with protecting property rights in Ukraine. Since the crash of 2008, trading volumes on Ukraine's largest stock exchanges (PFTS, Perspektiva, Ukrainian Exchange) are negligible and total market capitalization remains lower than at the start of 2008.

Domestic government bonds (DGBs) represent an alternative to deposits for small investors, but attempts to draw these private individuals into buying bonds have largely been unsuccessful. Today, investors can buy hryvniaand foreign currency-denominated DGBs, but a material return is only possible by investing an amount that is quite large for an ordinary household (starting from UAH 100,000).
For comparison: the average amount of bank deposit as of the end of Q1 2019 was UAH 10.63 thousand.

Nevertheless, the current development of the DGB market looks promising. Starting with the 2008 crisis and the monetization of newly issued debt by the NBU to solve budget and quasi-budget problems, the share of DGBs in the NBU's total portfolio grew, reaching $77 \%$ of all traded DGBs in 2015. As a result, the government was not motivated to place debt in the market. That motivation appeared only after the NBU committed to avoid fiscal dominance and stop buying up DGBs (through gradual redemption, the NBU's share of DGBs has decreased to $44 \%$ as of the end of Q1 2019). This spurred the market development. Today, banks hold the dominant position (48\% of all traded DGBs). However, almost $50 \%$ of the portfolio held by banks includes those DGBs that were issued to recapitalize the banks. Other participants hold a minimal market share, but their positions are growing. For instance, DGBs held by private individuals account for around $1 \%$, but their total holdings have grown from UAH 42 million in 2015 to UAH 8 billion as of end of Q1 2019. Since individual term deposits total UAH 330 billion, private individuals represent an attractive pool of potential investors. To manage liquidity, the corporate sector also uses DGB; corporates account for 3\% of all traded DGBs, with a 6:1 ratio of corporate term deposits to DGBs.

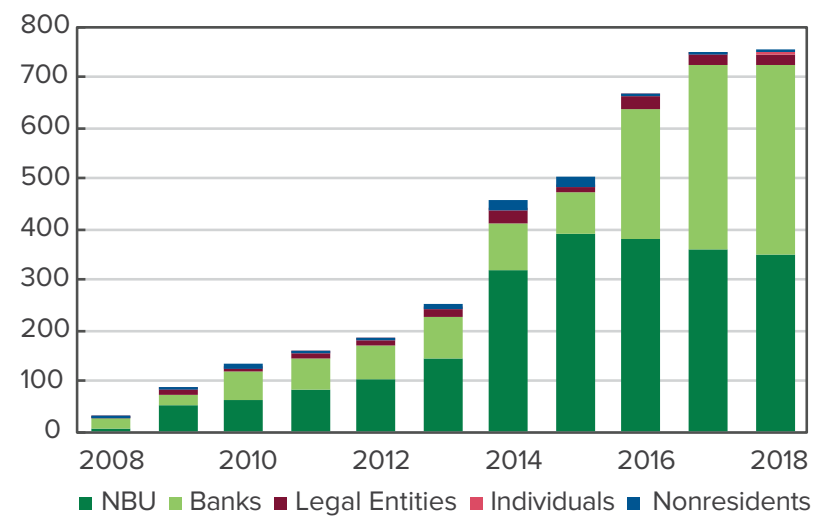

Figure 4. Holders of Domestic Government Bonds, UAH billion, nominal prices.

Source: NBU.

The structure and sophistication of the financial sector help define a country's dominant MTM channel and how fast the macro environment reacts to changes in monetary policy. The asset price channel is more important in countries with a sophisticated stock market, while the interest rate and lending channels are more important in countries with a dominant banking sector.

The depth of the banking sector's effect on the economy is usually measured by the ratio of loans to GDP. The higher this indicator, the greater the impact of changes in monetary policy on the economy. In Ukraine, this ratio was 30\% in 2018, one of the lowest indicators in Central and Eastern Europe (see Figure 5). That ratio has decreased over the past four years, driven by the economic recession that limited new lending opportunities amid the significant growth of nominal GDP due to high inflation. 


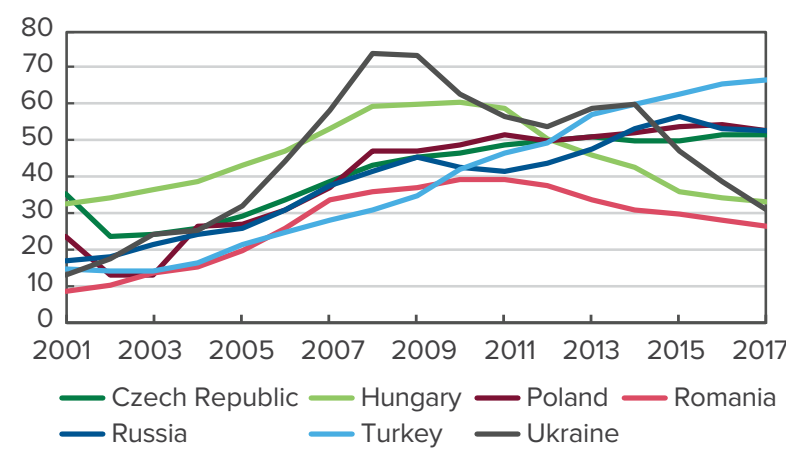

Figure 5. Ratio of Private Sector Loans to GDP, \%, 2001-2017. Source: World Bank.

Moreover, a substantial percentage of total loans in Ukraine were nonperforming loans: $53.2 \%$ at 82 solvent banks as of the end of Q1 2019. State banks accounted for $65 \%$ of all nonperforming loans, including $82 \%$ at the nationalized PrivatBank. On the brighter side, most of these nonperforming loans were reserve-backed. Still, such a substantial percentage of nonperforming loans complicates a bank's normal operation. The low level of financial intermediation translates into a low effect of interest rate changes in the financial sector on the rest of economy.

Before the 2008 crisis, banks in Ukraine were actively lending money, often not overly concerned with borrower's quality. Loans to individuals doubled every year from 2005 to 2007. A substantial percentage of loans were provided in foreign currency ( $51 \%$ of all loans to resident borrowers, including $62 \%$ of all loans to households on the eve of the crisis as of the end of Q3 2008). This included loans to individuals and businesses without foreign-currency income (see Figure 6). After the hryvnia depreciated sharply and the economy tanked, instances of nonpayment increased drastically. Many banks were concealing the real quality of their credit portfolios, while the NBU failed to maintain proper control. Therefore, the formal amounts of nonpayment in 2009-2013 were substantially underreported.

Significant structural changes in 2014-15, most importantly the loss of control over part of Ukrainian territory and a sharp devaluation (when the hryvnia lost more than two-thirds of its value against the US dollar), led to serious problems in

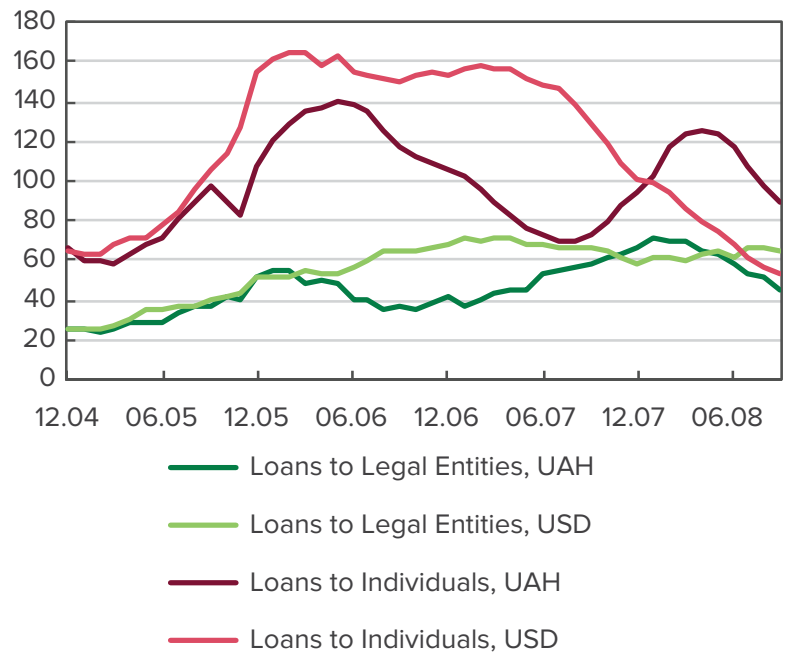

a) Year-on-Year Growth for Main Groups the banking system. In response, the NBU fundamentally changed its approach to banking supervision, no longer concealing the problems accumulated in the past. As a result, 87 banks which as of the beginning of 2014 held 31\% of the banking system's total assets were declared insolvent in 2014-2017. Moreover, to maintain the viability of the banking system, the largest Ukrainian bank, PrivatBank, was nationalized at the end of 2016. This measure led to the fact that state-owned banks hold more than half of total assets in the banking sector (see Figure 7).

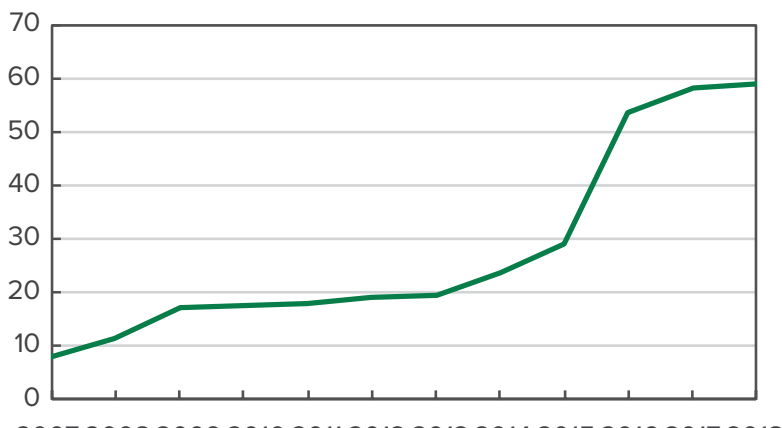

200720082009201020112012201320142015201620172018

Figure 7. Share of State-Owned Banks in Total Assets of the Banking System as of Year-End, \%, 2007-2018. Source: NBU.

Intense competition between banks during the lending boom of 2004-2008 yielded a situation in which the largest banks did not dominate, as they do in most of the neighboring countries. The crises of 2008-2009 and 2014-2017 drastically changed the situation: as of the end of 2017, the five largest banks held $62 \%$ of all assets. As of the end of 2017, the Herfindahl-Hirschman Index for the Ukrainian banking system was 0.12, close to the EU's 0.11 in 2016 (see Figure 8). The higher the number, the more concentrated and less competitive a market.

Another indicator - the banking system's net interest income - can indirectly describe the competitiveness of the banking services market. The more intense the competition, the lower this indicator should be. In Ukraine, it stood at 2.9\% of total assets as of the end of 2017 , close to that indicator in peer countries (see Figure 9).

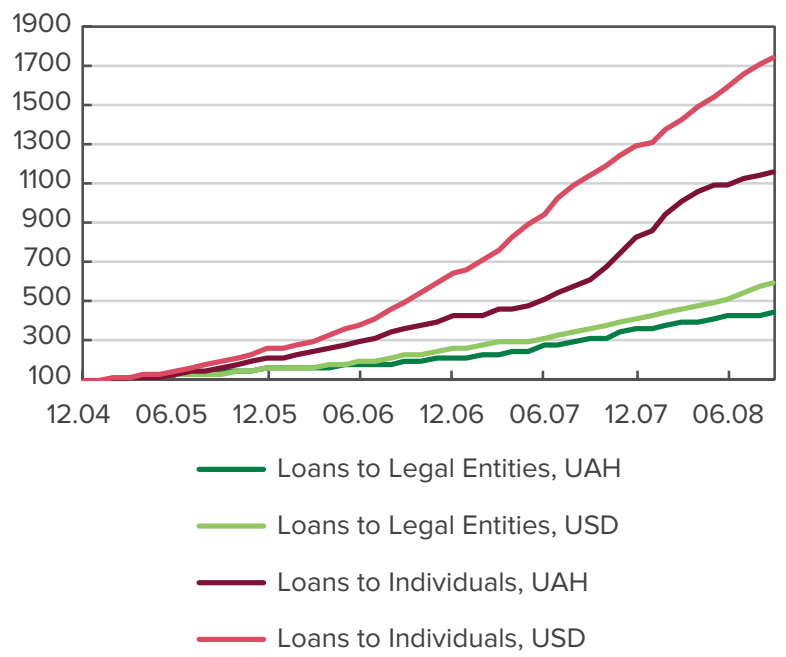

b) Cumulative Growth for Main Groups, December $2004=100.0$

Figure 6. A Surge in Lending Before the Global Financial Crisis, December 2004 - September 2008. Source: NBU. 


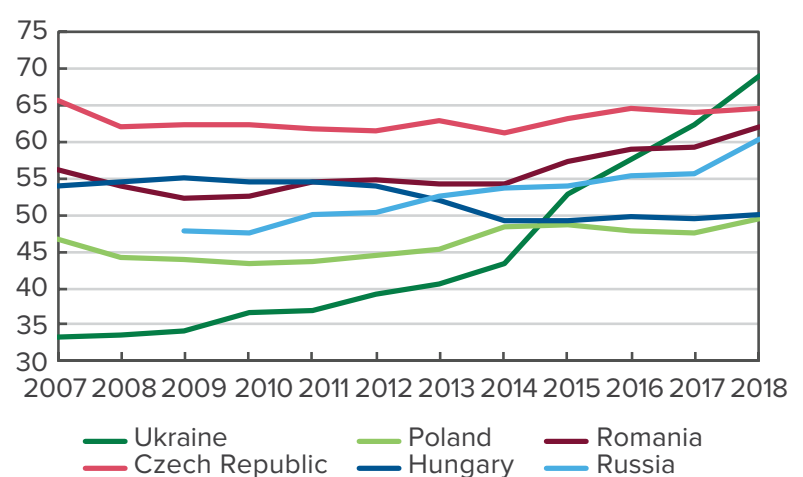

Figure 8. Share of Assets Held by a Banking System's Five Largest Banks, 2007-2018, \%.

Sources: NBU, ECB, Central Bank of Russia.

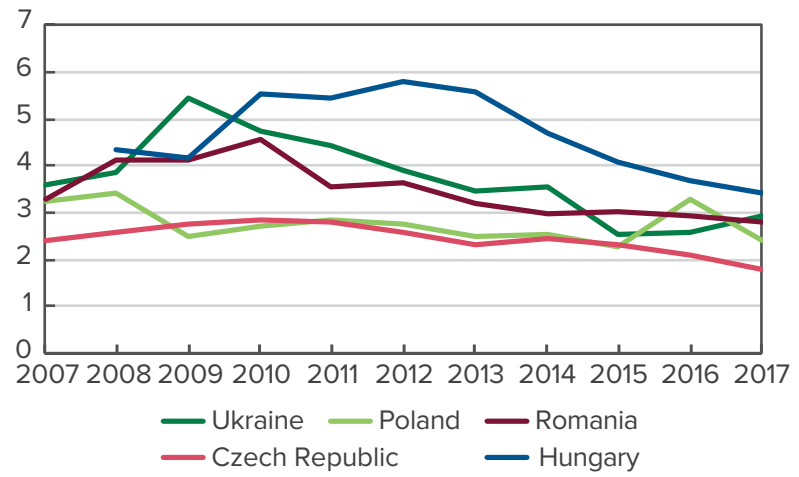

Figure 9. Net Interest Income, \% of total assets, 2007-2017. Source: NBU, ECB.

Lending to the real sector in Ukraine is spread unevenly, with businesses accounting for $82 \%$ and households for just $18 \%$. For comparison, in neighboring Poland, businesses accounted for $35 \%$ and households for $65 \%$ as end-2018; in Romania, this ratio was $42 \%$ vs. $58 \%$, respectively.

The level of lending to individuals in Ukraine is extremely low by international standards: only 6\% of GDP (with the share of performing loans at just $3 \%$ of GDP). These loans can be divided into two groups: (1) the result of past (prior to the 2008 crisis) lending in foreign currency (39\% of all individual loans and $97 \%$ of non-performing loans), and (2) new hryvnia-denominated consumer loans, mostly shortterm. Short-term consumer loans traditionally come at a high interest rate, because the risk of default is higher and the process of recovering loaned funds is costly for banks. Since the main element that determines the loan interest rate is risk, not the cost of funding, consumer loans globally show little reaction to changes in the key rate, which limits the effect of MTM via this channel.

A major contributor to the low level of lending to individuals has been the near-discontinuation of mortgage lending. The mortgage freeze, which began with the 2008 crisis, stems from two factors: the sharp decline of the USD-denominated value of real estate with expectations of a further drop in prices (which reduces the value of real estate as a collateral), and the ban on lending to individuals in foreign currency. Due to the difference in interest rates on mortgage loans, borrowers preferred foreign-currency loans (as in neighboring countries, especially in Russia and Poland).

Almost half of loans to businesses $(49 \%$ as of the end of Q1 2019) were issued for up to one year. A substantial portion of those were to fund working capital. At the same time, companies have traditionally funded longer-term investment using equity. This has two effects on the MTM. Firstly, since the transmission of the key rate to short-term loan rates takes place faster and to a larger degree than to long-term loan rates, the high percentage of short-term loans enhances the power of the MTM. Secondly, a significant percentage of investments outside the banking system may weaken the effect of the key rate on the economy.

Deposits from individuals and businesses are the main source of funding for the banking system $180 \%$ of aggregate liabilities as of the end of Q1 2019). Foreign loans are also substantial and account for another 13\% (see Figure 10).

Before the 2008 crisis, the percentage of foreign loans, especially loans taken by banks from western banking groups had been growing rapidly: up to $32 \%$ of total liabilities as of the end of 2007. After the 2008 crisis, the share of loans in liabilities increased at first (to $43 \%$ as of the end of Q1 2009) because the loans were in foreign currency, but then began to decrease as loans were repaid and/or these funds were converted into bank equity.

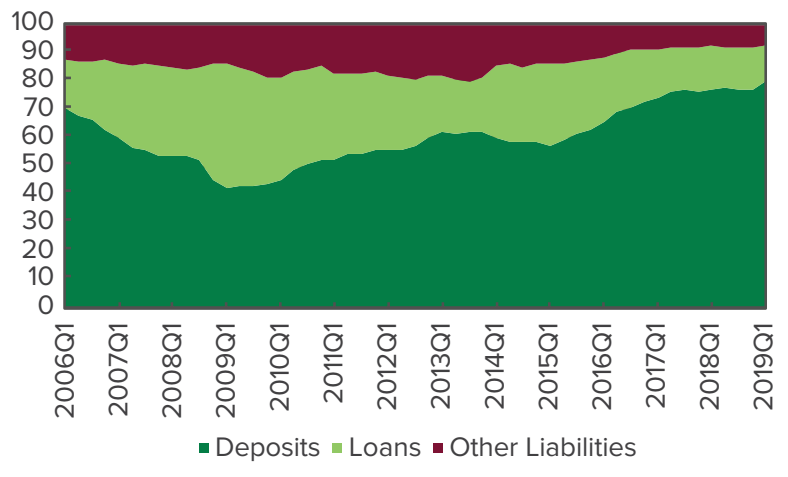

Figure 10. Structure of the Banking System's Liabilities, 2006-2019, \% Source: balance sheets of NBU deposit corporations.

As of the end of Q1 2019, 58\% of all deposits were in hryvnia. That is almost the same level as at the end of 2013 (56\%), on the eve of the hryvnia's depreciation. Even with the significant fluctuations of the exchange rate, the share of hryvnia-denominated deposits has been relatively stable over the last 10 years (ranging from $41 \%$ to $69 \%$ and averaging $56 \%$ ), so a substantial change in the near future is unlikely. The gap between interest rates on hryvnia and foreign-currency deposits can push depositors towards hryvnia products, but this can be a lengthy process.

A significant dollarization of deposits somewhat limits the effectiveness of the MTM, and de-dollarization can increase its effectiveness. At the same time, the experience of other countries proves that interest rates on deposits by individuals - the basis of funding - react only partially to changes in the key rate. In countries of Central and Eastern Europe, the pass-through is close to 0.7 (Égert \& MacDonald, 2008), and in countries of the European Monetary Union, this indicator is close to 0.8 (ECB Monthly Bulletin August 2009). Moreover, this pass-through is much lengthier than in the case of loans (e.g., see: De Bondt et al., 2005).

The Ukrainian banking system is also marked by a prevalence of short-term deposits. As of the end of Q1 2019, $49 \%$ of deposits were call deposits and another $35 \%$ had a term of up to one year. Deposits with a term greater than two 
years held just a 3\% share. On the one hand, short maturity allows interest rates to adapt more quickly to changes in market conditions, while on the other hand, they expose the banking system to deposit outflow risk. To control this threat, in March 2018, the NBU introduced ${ }^{7}$ a new prudential norm for Ukrainian banks: the Liquidity Coverage Ratio (LCR), which became binding effective 1 December 2018.

\section{THE EFFECTIVENESS OF MTM CHANNELS}

The significant changes to Ukraine's monetary policy approach and to the country's financial system described in the previous section place constraints on an empirical analysis of the MTM in Ukraine. We therefore focus on an econometric evaluation of the first stage of the MTM: the effect of monetary decisions on financial market indicators. We will analyze the effect of the second stage of the MTM (the impact of changes in financial market indicators on macroeconomic development) using economic theory and the results of empirical studies for other countries, first of all, countries of Central and Eastern Europe (CEE) with transitional economies and similar characteristics to Ukraine's economic and financial system.

After that, we will analyze the effectiveness of the MTM through its five key channels: interest rates, lending, exchange rates, asset prices, and expectations (Mishkin, 1995; Vonnak, 2007).

\subsection{Interest Rate Channel}

The transmission of a signal from the key rate (via shortterm interbank market rates) to long-term interest rates for financial instruments and to interest rates on bank loans and deposits is the key element of a traditional interest rate channel.

With a change in interest rates on bank loans and deposits, the preferences of economic agents for current consumption, investment, and saving should change. Rising interest rates encourage savings as opposed to current consumption and reduce investments. That should result in a slowdown of inflation and/or deflation due to a decrease in aggregate demand.

\section{First Stage: the Effect on Market Interest Rates}

In each stage, decisions to change interest rates are affected by not only the key rate (and the central bank's instruments pegged to it, such as certificates of deposit and refinancing loans) but also the economic situation, the structure of the banking system, access to alternate sources of financing, and more.

Another important feature of the money market is the interchangeability of resources, which makes its participants price takers, unlike in the main markets of funding liabilities available to banks: deposits and debt. Therefore, the money market can be seen to be in perfect competition, where interest rates gravitate toward the central bank's key rate. At the same time, interest rates on bank deposits and other liabilities are greatly affected by the business models of banks, the characteristics of the financial system, and other institutional factors.

A telling example is Poland, where spreads between money market rates and interest rates on bank deposits and loans increased after the crisis of 2008. Before the crisis, the transmission of money market rates to deposit and loan interest rates was almost full (Stanisławska, 2014). At the same time, the median ratio of loans to deposits was increasing significantly, which indicated the deposit base was covering a shrinking proportion of the credit portfolio.

After the crisis, banks began to borrow less actively on the money market and more actively on the individual deposit market. This caused a widening of the spread between deposit interest rates and money market rates, while the share of interbank loans in the structure of bank assets decreased (Kapuściński \& Stanisławska, 2016). Even in 2014, six years after the crisis, the spread between money market rates and interest rates on individual deposits remains higher than before the crisis.

Recent studies of monetary transmission via the interest rate channel in Poland (Kapuściński et al., 2016; Chmielewski et al., 2018) show that in 2001-2017, the key rate fully transmitted to money market rates in all cases except shortterm interbank rates (one-week and one-month WIBOR ${ }^{8}$ ), which means the transmission is not different from one at $5 \%$ statistical significance level. The non-full transmission in the latter two cases is the result of the global financial crisis of 2008-2009, which significantly increased shortterm uncertainty. Further transmission of money market rates to interest rates on business and individual deposits indicates full long-term transmission for all except shortterm deposits (1 and 3 months for individuals and 1 month for business deposits). The non-full transmission is also related to the crisis: banks were actively taking in short-term deposits during the crisis, and the increasing competition in that segment caused the deviation. According to a more recent study (Chmielewski et al., 2018), there is incomplete transmission to interest rates on property loans for individuals (0.65-0.76), while the transmission to loan interest rates for businesses is statistically higher than one (1.11).

Below we analyze the relationship between money market rates and bank rates in Ukraine. The correlation analysis presented in Table 2 shows a significant dependence between the key rate (directly) and money market rates and loan and deposit rates since 2015 . The correlation ratio for the daily raw data series (i.e., without discarding unusually high or low values) varies from -0.12 (key rate and interest rate on short-term household loans) to 0.92 (overnight rate and interest rate on short-term business loans). Even visually, the close relationship is evident between rates on short-term business loans and the overnight and key rates (see Figure 11).

In recent years, Autoregressive-Distributed Lag (ARDL) was the main approach used to assess the effect of overnight rates on other banking system rates. ARDL was used, for example, for Poland by Chmielewski et al. (2018) and for Russia by Nguyen et al. (2017). An important advantage of ARDL models is the possibility to explore time series that are stationary at levels or first differences, i.e. I(0) and I(1),

\footnotetext{
${ }^{7}$ Resolution 13 of the NBU Board of 15 February 2018 implementing the Liquidity Coverage Ratio (LCR), and Decision 101-rsh of the NBU Board of 15 February 2018 approving the Methodology of Calculating the Liquidity Coverage Ratio (LCR)

${ }^{8}$ WIBOR: Warsaw Interbank Offer Rate
} 
Table 2. Correlation Ratios from January 2015 to December 2018 (daily data).

\begin{tabular}{l|c|c}
\hline & $\begin{array}{c}\text { Overnight } \\
\text { Rate }\end{array}$ & Key Rate \\
\hline Overnight rate & 1.00 & 0.96 \\
3-month deposit & 0.55 & 0.76 \\
\hline 6-month deposit & 0.52 & 0.73 \\
9-month deposit & 0.57 & 0.75 \\
12-month deposit & 0.49 & 0.70 \\
Short-term individual loans & 0.19 & -0.12 \\
Long-term individual loans & 0.37 & 0.24 \\
Short-term business loans & 0.92 & 0.87 \\
Long-term business loans & 0.27 & 0.39 \\
Key rate & 0.96 & 1.00 \\
\hline
\end{tabular}

Source: own calculations based on NBU data.

as variables. ${ }^{9}$ Since most macroeconomic variables are non-stationary at levels, it significantly increases modeling options.

As shown in Table 3, variables are mostly non-stationary, have a unit root at levels and are stationary at first differences. The table shows the results of two key tests: PP and ADF

The model is as follows:

$$
\begin{gathered}
y_{t}=\alpha_{0}+\alpha_{1} y_{t-1}+\cdots+\alpha_{n} y_{t-n}+\beta_{0} x_{t}+ \\
+\beta_{1} x_{t-1}+\cdots+\beta_{k} x_{t-k}+\varepsilon_{t},
\end{gathered}
$$

where $y$ is the dependent variable representing a function of its own previous values (autoregression) and of the current and previous values of the independent variable $x$ (distributed lag). An additional advantage of this model for our analysis is the ability to interpret the obtained ratios as short- and long-term effects. Shortterm effects are the ratios of direction from the model:
Table 3. Stationarity Tests, Data at Levels and First Differences for Weekly Series for the Period from 25 December 2015 to 14 December 2018

\begin{tabular}{l|c|c}
\hline Variable & Test & Statistics \\
\hline Overnight rate & PP & -0.90 \\
& ADF & -1.03 \\
\hline Overnight rate & PP & $-170.73^{* * *}$ \\
& ADF & $-4.66^{* * *}$ \\
\hline \multirow{2}{*}{ oan rate $^{+}$} & PP & -0.67 \\
& ADF & -0.13 \\
\hline
\end{tabular}

${ }^{+}$for short-term business loans.

${ }^{* * *},{ }^{* *},{ }^{*}$ denote significance at the $1 \%, 5 \%$, and $10 \%$ levels, respectively.

for example, the effect of an independent variable of the current period is $\beta_{0}$, with a lag of one period is $\beta_{1}$, and so on. For a long-term period, we assume equilibrium, i.e. $y_{t}=y_{t-1} \ldots=y_{t-n}, x_{t}=x_{t-1}=\cdots=x_{t-k}$, which allows the formula to be shortened to:

$$
y_{t}=\frac{\alpha_{0}+x_{t} \sum_{0}^{t-k} \beta_{i}+\varepsilon_{t}}{1-\sum_{1}^{t-n} \alpha_{i}}
$$

which gives the following formula for the long-term effect of an independent variable:

$$
\gamma=\frac{\sum_{0}^{t-k} \beta_{i}}{1-\sum_{1}^{t-n} \alpha_{i}}
$$

Since the transmission mechanism only came into effect recently and, as stated above, transmission make take several months or even years, attempts to assess the effect using this model mostly produce no statistically significant ratios $^{11}$. The exception is the model where interest rates

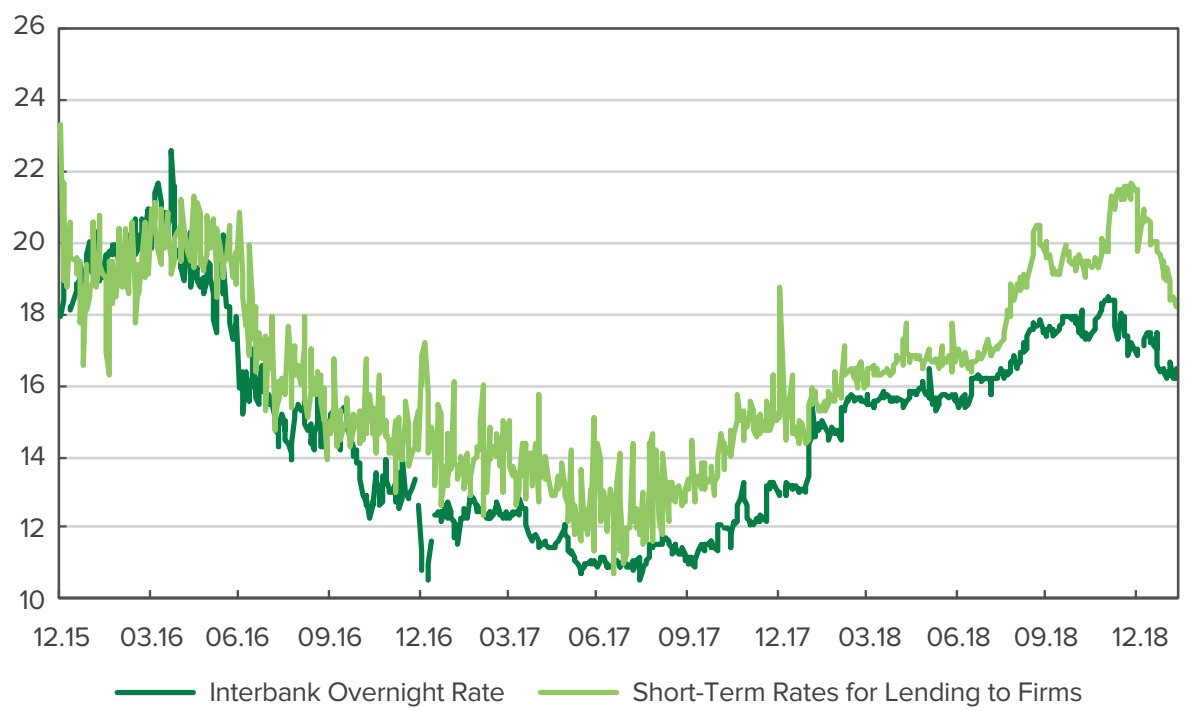

Figure 11. Similarity in Fluctuations between the Overnight Rate and Interest Rate on Short-Term Loans to Businesses. Source: NBU.

\footnotetext{
${ }^{9}$ For details, see: Pesaran et al. (2001), Pesaran \& Shin (1999).

${ }^{10}$ The zero hypothesis for Phillips-Perron (PP), Augmented Dickey-Fuller (ADF) is the existence of a unit root.

${ }^{11}$ Traditionally, these models are based on monthly data. If we assume that inflation targeting began in 2016 , we would only have 36 surveys from January 2016 to December 2018, which is insufficient for an in-depth statistical analysis.
} 
on short-term business loans depend on the overnight interbank rate based on weekly data (Table 4).

The model's econometric specification: ${ }^{12}$

$$
\Delta y_{t}=\alpha_{0}+\alpha_{1} y_{t-1}+\alpha_{2} y_{t-2}+\beta_{0} x_{t-1}+\varepsilon_{t} .
$$

Table 4. Results of Assessing the Dependence of Interest Rates on Short-Term Business Loans on the Overnight Rate for Weekly Series for the Period from 25 December 2015 to 14 December 2018.

\begin{tabular}{l|c}
\hline & Interest Rate \\
\hline Intercept & $0.745^{* *}$ \\
& $(0.318)$ \\
\hline Loan-1 & $-0.391^{* * *}$ \\
& $(0.080)$ \\
\hline Loan-2 & $0.174^{* *}$ \\
& $(0.079)$ \\
\hline Overnight & $0.187^{* * *}$ \\
& $(0.048)$ \\
\hline Adj. $\mathrm{R}^{2}$ & $10.36^{* * *}$ \\
$\mathrm{~N}$ & 0.15 \\
\hline
\end{tabular}

${ }^{* * *},{ }^{* *},{ }^{*}$ denote significance at the $1 \%, 5 \%$, and $10 \%$ levels, respectively. Standard errors are reported in parentheses.

According to this model, the weekly pass-through level is $19 \%$ (for the overnight rate, which in the event of full passthrough must not be statistically different from one). At the same time, the aggregate pass-through level should be $15 \%$ (the estimate based on the formula for a long-term effect stated below). The fact that even for such a short period as one week the pass-through level was almost one-fifth of the full transmission shows that interest rates on short-term business loans react quickly enough to changes in the key rate. The fact that the expected long-term transmission is not full indicates that other factors have a substantial effect on the formation of interest rates. In particular, a negative coefficient on the first lag of a dependent variable proves significant interest rate fluctuations even when using weekly data, which in turn is caused by low market volumes, so that even a single loan can decisively influence the interest rate. If we use only data from 2017 (to remove the possible structural shift in money market rates due to the PrivatBank nationalization), the short-term effect would be more significant (about 30\%), but the statistical significance of most coefficients would be much lower.

One area for further study is an evaluation of the interest rate channel at the micro level. Kapuściński (2017) evaluates the performance of this channel based on individual rates of Polish banks and on their balance sheets. This approach allows the researcher to check the heterogeneity of the bank's reaction to the key rate change. In particular, Polish banks with worse indicators (such as a higher share of bad loans) respond to a rate hike by cutting lending. Other studies show that the characteristics of a bank like its size, owner type (domestic or foreign, public or private), and others determine to a large degree the bank's market behavior. Therefore, disaggregation can be important for a more accurate assessment of the impact of monetary policy.
The yield curve is an important concept that sits at the junction of the interest rate and expectations channels (i.e. the dependence of risk-free asset rates on their redemption term). In Ukraine, the NBU forms the short part of the yield curve: overnight deposits and 14-day certificates of deposit. The Finance Ministry forms the long end (DGBs with maturity from 6 months to several years ${ }^{13}$ ). Economic agents can use yield curve data when determining the price of financial assets and derivatives, for risk management purposes or to form expectations about future monetary policy.

Theoretically, the yield on DGBs depends on the current value of money (defined by the key rate), anticipations of possible changes in the value of money, and the term premium. For market agents, the yield on short-term DGBs is the direct continuation of the yield on money market instruments (1- and 14-day certificates of deposit).

Despite the increasing volume and liquidity in recent years, the government securities market remains relatively shallow. Because of that, the transmission of the key interest rate to yields on government securities is fast and full. The low level of engagement leaves room for arbitrage. For instance, there is still a significant gap between the yield on government securities and interest rates on individual deposits. As the DGB market develops, that arbitrage opportunity should disappear.

In 2016-2018, the DGB yield on the primary market followed the movements of the key rate for all maturities. The rise of the key rate starting from the fall of 2017 caused corresponding growth in DGB yields across all terms, with the lowest growth rate observed for publicly placed DGBs with the term of 2 years. That reflects expectations of a decrease in rates during that period, which produced an inverted yield curve.

The yield on government securities reacts not only to changes in the NBU's key rate but also to liquidity conditions. For instance, the increase of DGB yields in late 2018 came amid a shrinking surplus of liquidity and growing interbank credit market rates (see Figure 12).

At the same time, the fast and significant reaction of the yield on government securities (especially longer-term ones) to current monetary decisions is atypical for a developed market. Their change must stem from both the expected future monetary policy and the political and economic events

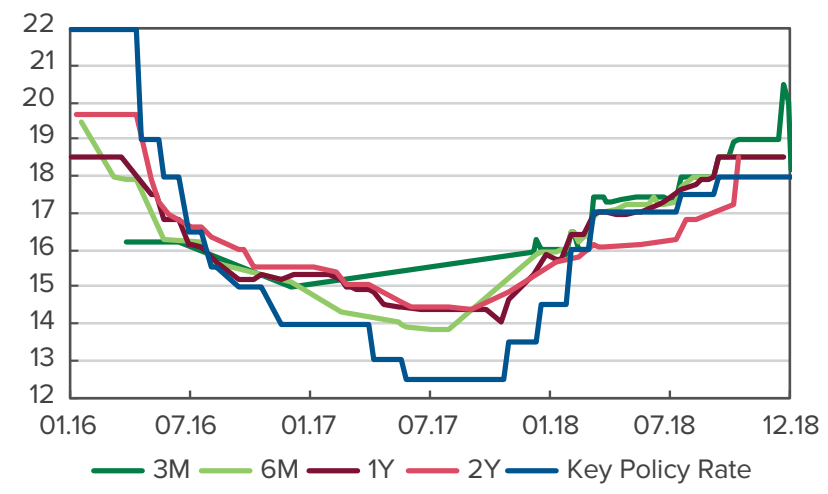

Figure 12. NBU Key Policy Rate and Primary Market DGB Yields, \%. Source: NBU.

\footnotetext{
12 The change of a dependent variable was used to focus specifically on the change. Since $\Delta y=y_{t}-y_{t-1}$, the formula can be written in levels, such as: $y_{t}=\alpha_{0}+\left(\alpha_{1}-1\right) y_{t-1}+\alpha_{2} y_{t-2}+\beta_{0} x_{t-1}+\varepsilon_{t}$

${ }^{13}$ Most DGBs with maturity of over two years were placed off-market, e.g., to cover Naftogaz of Ukraine NJSC's deficit.
} 


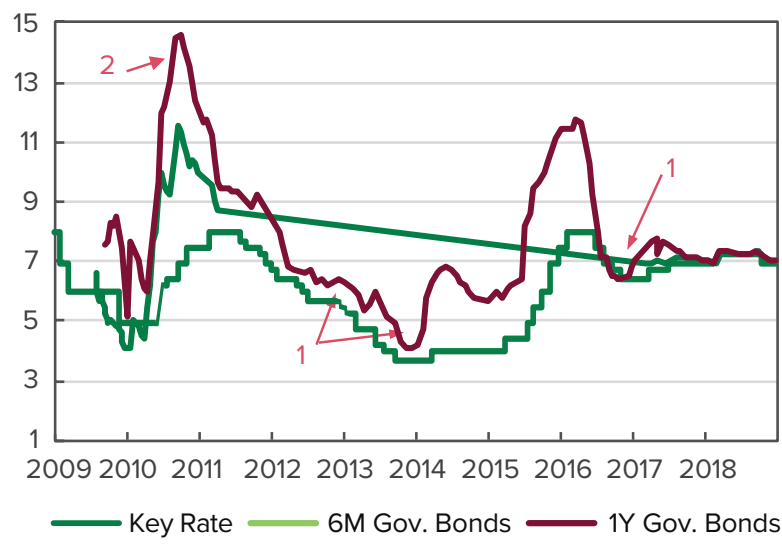

a) Government Bonds Yields in Georgia.

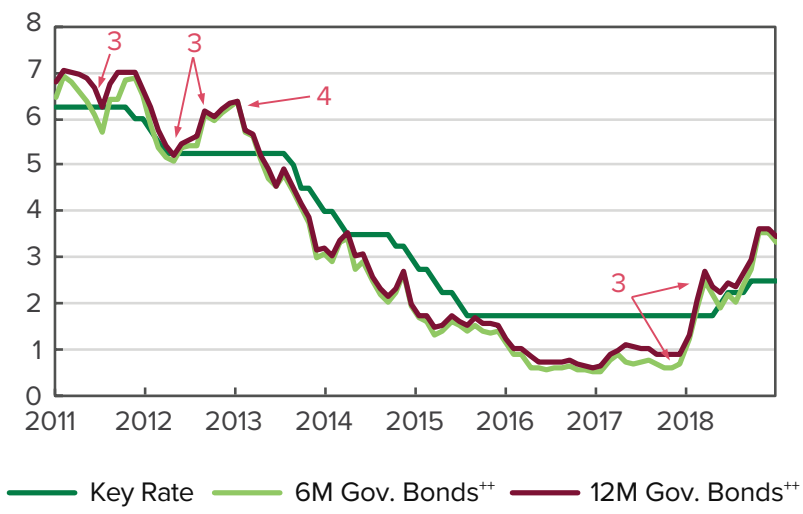

b) Government Bonds Yields in Romania (bid).

${ }^{++}$Bid, end of month

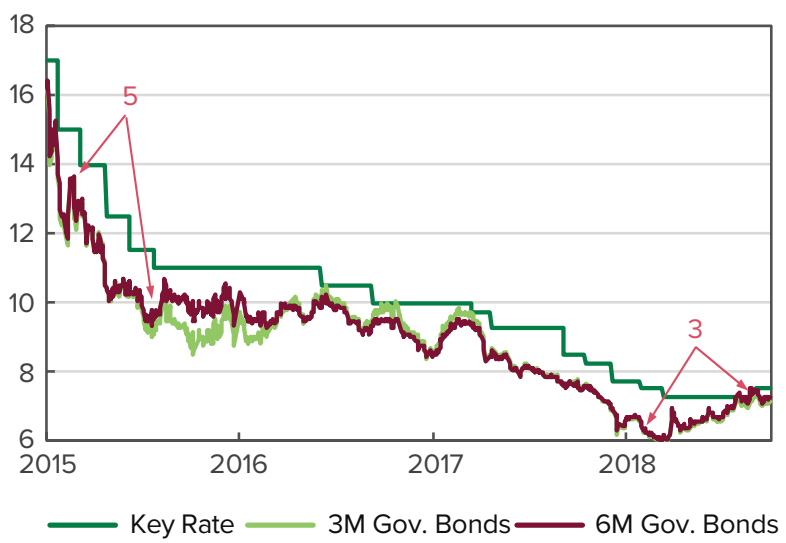

c) Government Bonds Yields in Russia.

1 - purchase of government bonds by non-residents;

2 - political instability;

3 - withdrawal of foreign investors from government bonds;

4 - including of government bonds in the JP Morgan/Barclays Indexes;

5 - raise of domestic investors demand on government bonds because of limited access to the International capital market (imposition of sanctions).

Figure 13. Key Rates and Yields on Government Securities in Countries with Inflation Targeting, \%. Source: central banks.

that brought about the change. Below are three examples of how that takes place in regional peer countries that also target inflation (see Figure 13).

As the market for government securities grows and their term increases, developing bond term structure models represents a prospective area of study.

The use of these models allows researchers to study the decomposition of the nominal bond yield on the real interest rate component (the anticipated rate and term premium) and the inflation component (expected inflation and premium for inflation uncertainty), which is important for monetary policy. On this basis, Abrahams et al. (2015) confirm the effectiveness of inflation targeting in the United Kingdom, which allows the Bank of England to offset the premium for inflation uncertainty in the yield on government securities.

A comparison of yields on hryvnia- and foreign currencydenominated DGBs helps evaluate the current premiums for the risk of a change in the exchange rate. A comparison of the distribution of prices for DGBs of the same type in the secondary market may provide information regarding the current level of liquidity (and uncertainty) on different time horizons.

Second Stage: the Effect of Interest Rates on Consumer and Investment Demand

Loan and deposit interest rates affect the decisions of economic agents regarding savings, current consumption, and investments. Higher rates should make savings more attractive and investments less economically beneficial.
Therefore, increases in interest rates should reduce aggregate demand and slow the growth of or even cause a decrease in price level.

The experience of developed countries and developing economies corroborates those findings. A study of the MTM in the Czech Republic, Poland, and Hungary (Darvas, 2013) using vector autoregression (VAR) models points out the specifics of transitional economies that switched from a fixed exchange rate to inflation targeting during the period of that study (1993-2011). Therefore, it is proposed to study these economies accounting for well-known 'Lucas critique', i.e. as economies whose reaction modified with a change of their monetary policy regime. Moreover, these economies underwent significant structural transformations, which also changes reaction in time. The EMU was used as the benchmark. Poland proved the closest of the three studied countries in terms of the euro zone's MTM reactions (shocks related to four variables: interest rate, prices, GDP, and exchange rate). This means that the loss of monetary independence (adoption of the euro) will be felt most in Poland if its business cycle does not match the EMU's cycle.

Several methods are used to assess the effect of changes in market rates on the components of aggregate demand (each method has strengths and weaknesses). The National Bank of Poland (Chmielewski et al., 2018) uses various vector autoregression (VAR) models, which have an advantage in their low dependence on theory, as well as semi-structural and structural models based on a deviation of all variables from the trend with the assumption that they will revert to the trend over the long-term. 
Most of the aforementioned models show the existence of transmission, with the effect of interest rate changes visible on the exchange rate, GDP growth, price levels, and unemployment rates. At the same time, the quantitative results vary.

Another popular area of study for the interest rate channel involves the use of data from companies' balance sheets to study the effect of changes in market interest rates on their investment decisions. These methods allow researchers to use large data sets to obtain statistically significant conclusions. For example, Kátay and Wolf (2004) use a similar approach for Hungary and find that investments react quickly and significantly to changes in the price of capital.

It is also worth trying to assess the effect of the MTM in Ukraine using several models, as every group of models has its limitations. Assessments should first be done using macro models. Micro analyses of individual transmission chains can be added to them, starting with the pass-through from money market rates to rates at individual banks. In addition, companies' balance sheets can be used to study the effect of interest rate changes on investments.

Since most macroeconomic indicators that are likely to be affected by monetary policy are available only quarterly (i.e., GDP and gross fixed capital formation) or monthly (i.e., price indexes and industrial output), data sample since the country's transition to inflation targeting is rather short. That complicates the use of econometric models (and worsens their analytical and forecasting quality), in particular VAR. For example, the aforementioned studies by the National Bank of Poland had to be confined to five variables (inflation, GDP, money market rates, volume of loans disbursed, and exchange rate) because the addition of another variable (the unemployment rate, for example) significantly reduces the model's quality. The problem of short data sample can be mitigated somewhat with assumptions for how the relationship between some variables had been changing after the launch of inflation targeting.

As of today, market interest rates have a weak impact on aggregate demand and, therefore, on inflation. For example, in 2016-2018 Ukraine had relatively high real interest rates and at the same time high growth rates of private investment and consumption.

Several factors contributed to that situation. First, as we showed in Section 2.3, Ukraine's financial depth is lower than in other countries of Central and Eastern Europe, both in terms of banking intermediation and the volume of government securities held by households and the corporate sector. Second, during a long period of high and volatile inflation, both nominal and real interest rates were very volatile by international standards. That minimized the accommodation by economic agents of interest rate changes in their consumption- and investment-related decisions and, accordingly, minimized the traditional transmission via aggregate demand.

As international experience shows, the establishment of the first stage of monetary transmission and the adoption of inflation targeting both help increase the sensitivity of aggregate demand to interest rate changes. For instance, Kara et al. (2007) used methods of evaluating time-variable parameters to show that the effect of interest rates on the output gap and the effect of the output gap on inflation in
Turkey increased significantly after the launch of inflation targeting.

A gradual resumption of lending can also help strengthen the effect of changes in market interest rates on aggregate demand and inflation. Other important factors include a further expansion of the DGB market (along with an increase in bond maturities) and lower dollarization.

\subsection{Credit Channel}

Bernanke and Gertler (1995) started the discussion of the role of loan supply in strengthening the effects of monetary policy. The basic idea of the credit channel is as follows: tighter monetary policy leads to an increased premium for external financing due to imperfections in the credit market, such as the principal-agent problem and information asymmetry. As a rule, a borrower knows their own situation better than a creditor, allowing the borrower to better assess the chances of success for an investment project. Creditors are less confident in eventual success, and therefore, they demand a risk premium and also affect, to a certain degree, these chances by their own behavior. This asymmetry begets a premium for all types of external financing and leads to a gap between the cost of external and internal funds. That yields problems of adverse selection and moral hazard. As a result, an increase in the key rate by a central bank not only decreases aggregate demand but also reduces loan supply.

Within the overall credit channel, the lending channel and balance sheet channel act differently. In the lending channel, tighter monetary policy reduces credit resources in the banking sector. The balance sheet channel is based on the notion of a financial accelerator. Interest rate changes affect companies' net worth via cash flows and collateral value. Therefore, higher interest rates lead to a lower net worth and higher premium for external financing (loans).

Some evidence shows that the credit channel's contribution to the MTM is insignificant. Firstly, since the economic and financial crisis of 2014-15, commercial banks prefer to finance reliable borrowers regardless of monetary conditions. That is especially true of banks affected by the armed conflict; according to Pham et al. (2018), these banks tend to reduce loan supply, first of all in those regions located farther from their head offices. Secondly, a faster resumption of lending (loan supply) is restrained, especially by institutional factors, including a poor protection of creditor rights. Thirdly, large corporations (especially exporters) have an alternative to bank lending in the form of borrowing from their parent company or selling Eurobonds. Finally, the corporate sector is relatively independent of bank lending: loans financed just 5.3\% of investments in 2017.

In future, studies using a large sample of Ukrainian banks and corporations look to be a perspective area. That type of study would be able to identify loan supply factors other than demand for loans.

\subsection{Exchange Rate Channel} Rate

First Stage: the Effect of Interest Rates on the Exchange

The first stage of the exchange rate channel features a reaction by the exchange rate to interest rate changes. Uncovered interest rate parity is a simple assumption widely used in theoretical models. According to that condition, the 
difference between yields on assets in different currencies must compensate the expected change in the exchange rate and the risk premium.

According to theory, a hike in the key rate strengthens the domestic currency, all other conditions being equal. The transmission looks like this: following the key rate, all other rates in the economy grow as well, including the yields on tradable assets like stocks, bonds, and tangible assets. This yield increase makes them more attractive to foreign investment. That increases foreign currency supply locally and, barring interventions from the central bank, currency appreciation pressures.

For developing economies, risk premium shocks can be quite significant owing to changes in risk assessments and preferences by domestic and foreign economic agents.

That significantly complicates the measurement of effects from interest rate changes on the exchange rate. The use of correlations between the interest rate and the exchange rate may lead to incorrect conclusions as one needs to differentiate the effect of two factors on the exchange rate: risk premium shocks exogenous to monetary policy and monetary decisions alone.

In addition, an analysis of the relationship between interest rates and the exchange rate in Ukraine is complicated by the NBU's interventions on foreign exchange market to accumulate international reserves and smooth foreign exchange volatility. Moreover, foreign exchange restrictions constitute an obstacle to the free flow of capital and, therefore, lower the magnitude of the effect produced by interest rate changes on the exchange rate.

No studies have yet been done in Ukraine on the exchange rate effects from changes in interest rates and foreign-currency interventions. However, the latest cycle of key rate hikes suggests there is a strong relationship between monetary decisions and exchange rate trends.

In October 2017, the NBU started a cycle of monetary tightening by raising the key rate after the current and expected inflation rates exceed the targets for 2017 and 2018. The increase in the key rate led to an increase in DGB yields in early 2018. DGBs are perhaps the only liquid asset in Ukraine available to foreigners. In January-November 2017, before the rate increase, the average monthly placement of DGBs with a term of up to one year was less than UAH 600 million. The DGB placement volume increased by more than 10 times in January-February 2018, when the yield rose by approximately 1.6 p.p. The inflows of foreign currency into DGBs strengthened the hryvnia exchange rate from UAH 28.07/USD as on 1 January to UAH 26.95/USD on 28 February. Despite that appreciation, the NBU increased its interventions in the foreign exchange market.

In conclusion, the evidence in Ukraine confirms theoretical expectations. At the same time, the "all else being equal" condition is critical. The start of an election cycle or a serious deterioration in conditions on foreign markets can quickly change the hryvnia's strength trend even when rates are high.

Second Stage: the Effect of the Exchange Rate on Inflation and Economic Activity

The second stage of the exchange rate channel features the effect of its changes on macroeconomic indicators, particularly inflation. The exchange rate affects inflation not only directly via prices for imported goods and the effects on exported goods and production costs, but also via aggregate demand and balance sheet effects.

In Ukraine, the relationship between the exchange rate and inflation has traditionally been the strongest and transmission most rapid.

On one hand, that is a consequence of the high public attention to exchange rates because of the country's history of a hard currency peg. On the other hand, the Ukrainian economy is characterized by a high degree of openness (the ratio of trade turnover to GDP has consistently exceeded $100 \%$ ) and a high degree of dollarization.

In terms of the transmission to inflation, Faryna (2016) studied the nonlinearity of transmission effects on the basis of a panel autoregressive model with distributed lags. Faryna found that a significant devaluation of the exchange rate (more than $16 \%$ per quarter) leads to a high pass-through (0.2-0.3 during 12 months). At the same time, mild exchange rate fluctuations (between $3 \%$ and 16\%) do not lead to significant shifts in inflationary processes. Meanwhile, under conditions of the exchange rate strengthening the elasticity of inflation revealed to be quite low.

Shevchuk (2017) analyzed the difference in effects from anticipated and unanticipated changes in the exchange rate. His study of the industrial and agricultural sectors showed a lack of a reaction to anticipated changes in the nominal effective exchange rate (NEER) and a negative reaction to unanticipated changes in the NEER. At the same time, unanticipated changes in the exchange rate strengthen if the currency floats as it does currently in Ukraine.

The exchange rate also affects production costs. The same work by Faryna (2016) shows that PPI usually reacts more strongly to exchange rate fluctuations. Then, with a greater time lag it reflects in consumer prices as well.

In addition, according to the NBU's business expectations surveys, firms traditionally mention the exchange rate among the largest contributors to inflation.

However, we expect that the transition to inflation targeting and a floating exchange rate will lower the magnitude of transmission. Taylor (2000) first presented the argument that increased trust in monetary policy, which ensures consistently low inflation rates, reduces the effect from the exchange rate changes as the expectations channel will have already taken care of some of the effect. Taylor's work was followed by many studies based on theoretical models and actual data and concerning the effect of inflation targeting on the magnitude of transmission. The most popular study is by Bailliu and Fujii (2004), in which the authors review 11 developed countries and assess the transmission effect before and after the adoption of inflation targeting. The authors clearly differentiate periods of consistently low inflation with and without inflation targeting. They conclude that the adoption of inflation targeting does decrease the pass-though coefficient.

Another important aspect of the exchange rate channel is the role of foreign currency in the assets and liabilities of economic agents. Exchange rate fluctuations produce significant balance sheet effects, since both households and companies keep a significant portion of assets and 
liabilities in foreign currencies, primarily USD and EUR. As of the end of Q1 2019, 41\% of resident deposits were in foreign currency.

Historically, the hryvnia's real exchange rate has strengthened during periods of economic growth and weakened during crises. Those trends can be explained, first of all, by capital flows and the use of foreign currency loans to finance capital and production. During periods of capital inflows (usually when the global financial system has a surplus of liquidity) the hryvnia has strengthened in real terms, which has reduced the cost of foreign-currency loans and increased the corporate sector's net assets. Consequently, investments and production activity grew due to balance sheet effects. That was helped by the impact on costs as imported investment goods became cheaper as the hryvnia strengthened. Household purchasing capacity grew as well. On the other hand, the strengthening of the exchange rate reduced price competitiveness and cut into net exports. For that reason, Ukraine's foreign trade deficit has typically widened during periods of economic growth. During crises, the reverse took place through the same channels (balance sheet, costs, trade). Therefore, the effect of exchange rate fluctuations on economic activity in Ukraine is weak because the traditional trade channel is offset by effects from other channels.

\subsection{Asset Price Channel}

In theory, asset prices decline after a central bank raises its key rate (Mishkin, 1995). That is especially true of bonds (yields increase), as well as stocks and financial derivatives, particularly commodity futures.

Prices for those assets create a foundation for consumer prices and for the appraisal of collateral (especially real estate) and for real estate prices themselves. Then, asset prices influence consumption by households (via the wealth effect) and their liquidity.

This channel works best in countries with developed stock and commodity markets, like the US. In Ukraine, the capacity of the asset price channel is very low. The stock market is in an almost nascent state and stocks play no statistically significant role in the financial assets of households. The same is true of government securities (only UAH 6 billion as of the end of 2018).

Real estate plays a much greater role in household assets. However, considering the near complete lack of activity by commercial banks in mortgage lending, we believe the capacity of the asset price channel via real estate prices is very low.

The asset price channel may manifest itself, to a certain degree, via substantial amounts of foreign currency in cash held by households for savings. Tighter monetary policy that strengthens the hryvnia exchange rate thus reduces the real value of household savings in foreign currency. It may have an effect on long-term consumer and investment decisions by households.

\subsection{Expectations Channel}

Consistently low inflation creates advantages for economic growth via the anchoring of inflation expectations. In a theoretical model featuring a monetary policy that follows the Taylor rule, long-term inflation rate is defined as a central bank's target. Rational economic agents tie their interest rate anticipations to the central bank's reaction function and their long-term inflation expectations to the central bank's targets. This is based on the confidence that the central bank will carry out the appropriate policy to achieve its declared targets. As a result, such anchoring expectations to targets in itself mitigates the effects from various shocks, makes a strong response from the central bank to these shocks less necessary, and lowers the resulting losses in economic growth. When setting prices and wages, economic agents take into account the central bank's targets rather than short-term deviations of the inflation rate from the target under the effect of particular factors.

As a result, the capacity of this channel is driven by several elements:

1) The existence of central bank clear quantitative inflation target, and the consistency of monetary policy in achieving that target;

2) An efficient strategy of monetary communication, which serves as a connection between policymakers and economic agents;

3) The "rationality" of economic agents' inflation expectations, i.e. their use of all available information to forecast the future, including the central bank's actions taken to achieve inflation targets. The word "rationality" was intentionally placed in quotation marks because economic agents act rationally in any situation, which means their expectations are based on the information available to them. If a central bank has not shown a consistent monetary policy in achieving its declared targets in the past, economic agents will not consider its targets when forming their inflation expectations. On the contrary, if a central bank consistently conducts monetary policy aimed at reaching an inflation target, economic agents will expect the future inflation rate to be close to the target. That is called the "anchoring of expectations".

Therefore, the capacity of this channel is dependent on the degree of trust in the central bank and its monetary policy. The first two elements mentioned above can be quickly established if there is political will.

We focus primarily on the third element, because it defines the degree to which economic agents are capable of taking into account future events, including the central bank's policy, when forming expectations. In the end, this ability of agents to be forward-looking indicates the potential opportunities to anchor inflation expectations at the level of the central bank's target.

At the same time, it is worth reviewing the efforts to establish trust in the central bank and the creation of the new approach to monetary policy in Ukraine.

The transition to inflation targeting with a declaration of clear and, most importantly, irrevocable inflation targets in mid-2015, and the NBU's efforts to achieve those targets, have resulted in a significant and rapid decline of inflation expectations after the crisis (see Figure 14).

However, inflation expectations remained much higher than the NBU's targets, a consequence of the low trust in the NBU owing to historical memory and the experience of the most recent currency crisis of 2014-15. Overall, as 
the study by Coibion and Gorodnichenko (2015) shows, inflation expectations significantly depend on the USD-UAH exchange rate.

Moreover, the inflation expectations of various economic agents have been worsening since late 2017 in a large degree due to the consequences of powerful food supply shocks, sharp increases in social standards by the government, and high wage growth, particularly because of intense labor migration.

Notwithstanding a temporary but significant increase in actual inflation, as from mid-2016 to 2017, inflation expectations have remained largely inert. That is a sign of the potential of anchoring them at a lower level, provided the public trust in the NBU's monetary policy.

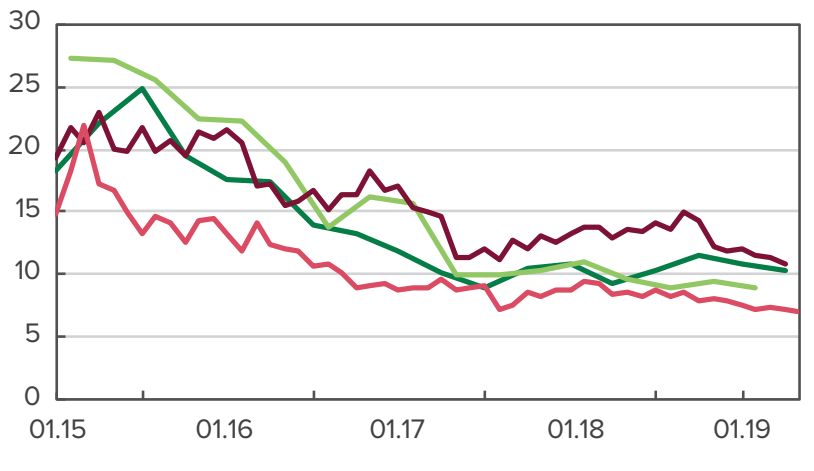

- Banks - Corporates — Households — Financial Analysts

Figure 14. Inflation Expectations for the Next 12 Months by Survey Respondents, \%.

Source: NBU.

Although unpopular, the interest rate hikes by the NBU in October 2017 - March 2018 created a foundation for an increase in trust in monetary policy and for an enhancement in the capacity of the expectations channel.
The NBU's implementation of best communication practices regarding monetary policy also contributed. These include the introduction since 2015 of the following elements that are standard for central banks that target inflation: 1) a public schedule of NBU Board meetings on monetary policy (eight annually since 2018); 2) regular press releases and press briefings featuring NBU Board members after every monetary decision; 3) publication of the Inflation Report with the NBU's macroeconomic forecast; 4) publication of Summaries of the Discussion on the Key Policy Rate at the Monetary Policy Committee.

To ascertain the rationality of expectations in Ukraine, we test hypotheses similar to those in studies of New Zealand (Ranchhod, 2003), Poland (Demchuk et al., 2012) and Hungary (Vonnák, 2007). The results of the tests of these hypotheses for Ukraine are just some proximity to reality because the time series are short and the periods they cover include economic crisis and changes in the monetary and foreign exchange regime in 2014-15.

The tested hypotheses include:

$H$ 1. The reaction of long-term forward rates to an unanticipated change of the central bank's key rate are negative (according to Rezessy (2005). If a central bank responds to growing inflation by raising its key rate, the short-term end of the yield curve for government securities increases. In doing so, the central bank is seen to act to tame inflation, which consequently lowers the long-term forward yield.

Because of the limited availability of the data, we can only show that result based on anecdotal evidence. In October 2017 - March 2018, the NBU raised its key rate from 12.5\% to $17.0 \%$ in four steps. Financials analysts did not anticipate the first two hikes. In other words, the market found out that the NBU is ready to defend its inflation target, even though it did not expect that tight policy in the past (see Figure 15).

Survey of financial analysts: What changes in monetary policy do you expect?

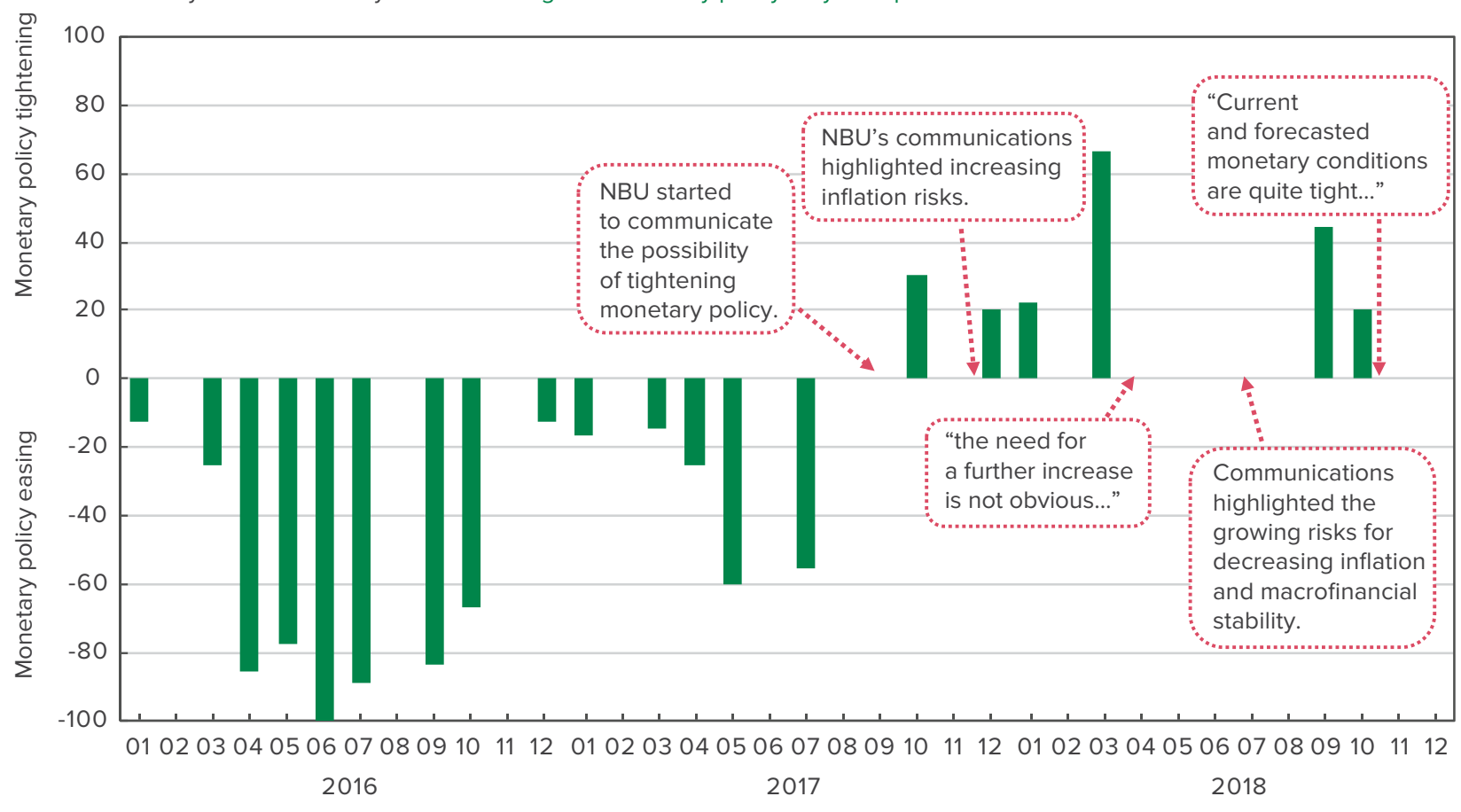

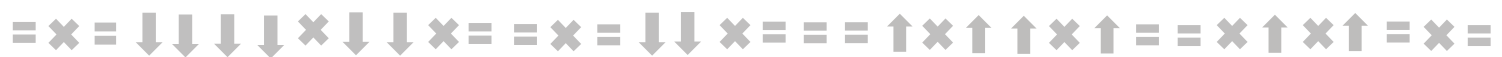

Decision on the Key Rate by the NBU $=$ Unchanged Increased Decreased Without Decision

Figure 15. Results of Surveys of Financial Analysts Regarding Changes in the Key Rate, \%. 
As a result, the current yield on DGBs increased, while forward rates were flat or decreased (see Figure 16). In other words, this channel may be effective and the market considers the NBU's behavior.

a) Based on the Nelson-Siegel Parametric Model $^{+}$

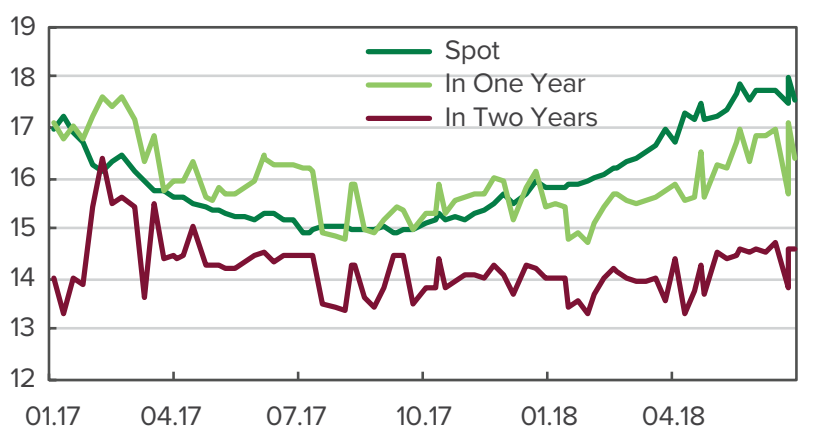

Based on the formula $f_{T-1,1}=\left(\frac{\left(1+y_{T}\right)^{T}}{\left(1+y_{T-1}\right)^{T-1}}\right)-1$
According to Ranchhod (2003), the mean error indicates the existence of bias when forming expectations, because it considers the deviation sign. A negative error indicates an understatement of expectations. In our case, that is

b) Based on Data for the Yield on DGB Transactions in the Secondary Market ${ }^{++}$

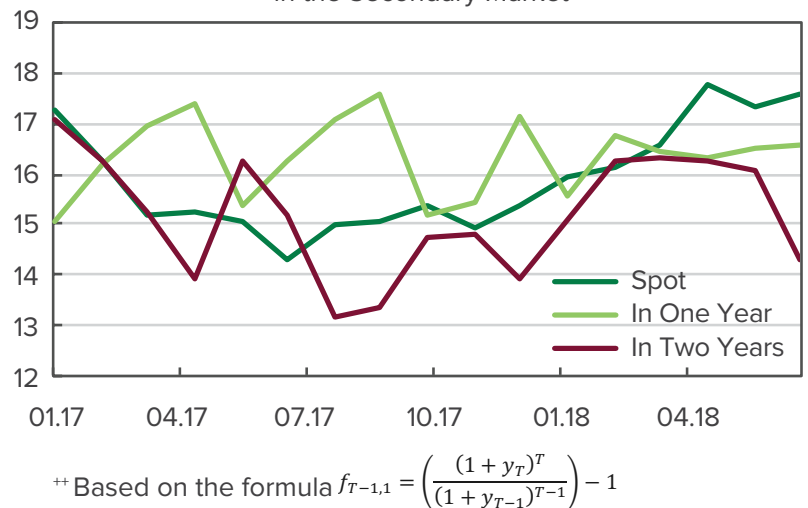

Figure 16. One-Year Forward Interest Rates on DGBs, \% p.a. Source: own calculations.

H 2. Inflation expectations are unbiased and/or mostly do not take into account currently observed price trends.

To check these hypotheses, we compare inflation expectations for the next 12 months with actual annual inflation in 12 months.

We assess the mean forecast error (ME), the mean absolute percentage error (MAPE), and the root mean square error (RMSE) for existing expectation series and compare them with a naïve forecast, meaning a forecast built on the assumption that the current value of an indicator will stay the same in the future.

Since different groups are surveyed more or less frequently, we provide separate results for the monthly expectations of households and financial analysts (see Table 5 ) and the quarterly expectations of firms and banks (see Table 6).

Table 5. Errors in Inflation Expectations of Surveyed Respondents in 12 Months.

\begin{tabular}{l|c|c|c}
\hline Expectation error & ME & RMSE & MAPE (\%) \\
\hline Households & -1.4 & 15 & 51 \\
Financial analysts & -6.7 & 17 & 39 \\
Naive forecast & 6.3 & 28 & 146 \\
\hline
\end{tabular}

Source: NBU, State Statistics Committee.

Period: July 2014 - December 2017. Variables:

inflation expectations of households and financial analysts for the next 12 months, CPI yoy, actual CPI with a 12-month lag used as a naïve inflation indicator.

Table 6. Errors in Inflation Expectations of Surveyed Respondents in Four Quarters.

\begin{tabular}{l|c|c|c}
\hline Expectation error & ME & RMSE & MAPE (\%) \\
\hline Firms & 0.9 & 14.7 & 72 \\
Banks & -2.1 & 15.7 & 59 \\
Naive forecast & 7.4 & 25.6 & 166 \\
\hline
\end{tabular}

Source: NBU, State Statistics Committee. Period:

Q3 2014 - Q4 2017. Variables: inflation expectations of firms and banks for the next four quarters, CPI yoy as of the last month of a quarter, actual CPI with a 4-quarter lag used as a naïve inflation indicator. what is observed for all respondent groups except firms, where it is positive but close to zero (Tables 4 and 5). This tendency towards an understatement of inflation became a consequence of serious unanticipated shocks that accelerated inflation during the surveyed period. This is especially true of 2015 and, to a lesser degree, 2017.

Nevertheless, the results are promising considering that the expectations have not been anchoring at high levels of actual inflation and have the tendency to decrease. Had expectations been observed at high levels, the error would have been significantly positive, as in the case of the naive forecast. With more experience in inflation targeting, these expectations can be anchored near the inflation target.

The expectations of all respondent groups for the indicators that take into account the relative value of deviation (but not its sign) are much more accurate than in the case of the naïve forecast (Tables 5 and 6). That shows that the respondents consider factors other than current inflation when forming expectations.

A test of the following hypothesis may help expand on that conclusion.

H 3. Inflation expectations are influenced by future inflation (forward-looking), not past (backward-looking).

Studies of the identification of backward- and forwardlooking components of inflation expectations typically have a common flaw: they cannot accommodate the unanticipated shocks that constantly affect an economy. When comparing expectations with actual inflation before and after survey (which was affected by unanticipated shocks), a greater correlation is seen with backward-looking inflation. Therefore, quantitative assessments suggest that inflation expectations are rational neither in developed economies like Sweden (Jonsson \& Österholm, 2012) nor in developing economies like India (Sharma \& Bicchal, 2018).

Still, a study of whether expectations are correlated with future inflation or if they are "anchored" only to inflation in the past is useful in any case. The degree to which the central bank's monetary policy can potentially influence expectations depends on that understanding. 
Table 7. Correlation between Expected and Actual Inflation Indicators (lagged and anticipated)

\begin{tabular}{lcccc}
\hline & \multicolumn{2}{c}{ Financial analysts } & \multicolumn{2}{c}{ Households } \\
\hline Months & $\begin{array}{c}\text { Backward-looking } \\
\text { inflation }\end{array}$ & $\begin{array}{c}\text { Forward-looking } \\
\text { inflation }\end{array}$ & $\begin{array}{c}\text { Backward-looking } \\
\text { inflation }\end{array}$ & $\begin{array}{c}\text { Forward-looking } \\
\text { inflation }\end{array}$ \\
\hline 0 & 0.76 & 0.76 & 0.77 & 0.77 \\
1 & 0.70 & 0.81 & 0.73 & 0.74 \\
2 & 0.64 & 0.81 & 0.70 & 0.70 \\
3 & 0.58 & 0.78 & 0.66 & 0.65 \\
4 & 0.53 & 0.74 & 0.61 & 0.60 \\
5 & 0.48 & 0.68 & 0.57 & 0.55 \\
6 & 0.43 & 0.62 & 0.51 & 0.49 \\
7 & 0.37 & 0.54 & 0.46 & 0.43 \\
8 & 0.32 & 0.48 & 0.43 & 0.37 \\
9 & 0.29 & 0.41 & 0.39 & 0.29 \\
10 & 0.24 & 0.32 & 0.36 & 0.22 \\
11 & 0.20 & 0.22 & 0.30 & 0.15 \\
12 & 0.15 & 0.11 & 0.26 & 0.08 \\
\hline
\end{tabular}

Source: NBU, State Statistics Committee. Period: July 2014 - December 2018.

Variables: inflation expectations of households and financial analysts for the next 12 months, yoy changes in CPI.

Table 8. Correlation between Expected and Actual Inflation Indicators (lagged and anticipated)

\begin{tabular}{lcccc}
\hline \multicolumn{2}{c}{ Banks } & \multicolumn{2}{c}{ Firms } \\
\hline Quarters & $\begin{array}{c}\text { Backward-looking } \\
\text { inflation }\end{array}$ & $\begin{array}{c}\text { Forward-looking } \\
\text { inflation }\end{array}$ & $\begin{array}{c}\text { Backward-looking } \\
\text { inflation }\end{array}$ & $\begin{array}{c}\text { Forward-looking } \\
\text { inflation }\end{array}$ \\
\hline 0 & 0.88 & 0.88 & 0.88 & 0.88 \\
1 & 0.89 & 0.74 & 0.83 & 0.79 \\
2 & 0.79 & 0.50 & 0.69 & 0.61 \\
3 & 0.62 & 0.23 & 0.51 & 0.36 \\
4 & 0.44 & -0.02 & 0.33 & 0.07 \\
\hline
\end{tabular}

Source: NBU, State Statistics Committee. Period: Q3 2014 - Q4 2018.

Variables: inflation expectations of firms and banks for the next four quarters, yoy change in $\mathrm{CPI}$ as of the last month of a quarter.

The cross-correlations presented above are highlighted where it is greater than $50 \%$. The results show that the expectations of all respondent groups have a future-oriented component. It is not surprising that financial analysts are most future-oriented (Table 7); their expectations correlate more with future inflation than with current inflation. They are better at forecasting and they already have a better understanding of the goals and the response function of the NBU's monetary policy. As for other respondent groups, their expectations are largely based on current inflation indicators (Tables 7 and 8).

Unfortunately, in-depth studies of pricing or wagesetting mechanisms in Ukraine and the effect of monetary policy on them, which could have allowed for a thorough study of the expectations channel, are unavailable today. Sufficient survey time periods (especially for the inflation targeting period), which could provide the basis for accurate conclusions for the properties of expectations, are also unavailable.

The adoption of the inflation targeting regime, the macrofinancial stabilization of recent years, and the NBU's interest rate hikes in October 2017 - September 2018 created the basis for a restoration of trust in monetary policy and for an increase in the power of the expectations channel.

An analysis of the available data on inflation expectations indicates that these expectations are influenced not only by current and backward-looking inflation, but also future expected inflation. Economic agents are better placed to forecasts than to simply use naïve forecasts. That is especially true of professional analysts, who already have a better understanding of the goals and the response function of the NBU's monetary policy. The inflation expectations of firms and households are still loosely tied to the NBU's targets. That is natural given the initial low degree of trust, short history of inflation targeting, and significant inflationary shocks of the last years.

The study's results suggest that after more time carrying out a consistent monetary policy aimed at ensuring price stability, inflation expectations can be anchored close to the NBU's inflation target.

This analysis can be expanded, but that would require more data, especially for timeframe during which the NBU has conducted monetary policy based on inflation targeting. 
Possible areas of study include:

1) Assessing the persistency of inflation expectations and the degree to which those stay close to the inflation target. This assessment could be based on a sufficient amount of data for the existing inflation targeting period;

2) Evaluation of the period in which inflation expectations return to the target level after a sizable price shock;

3) The effect of changes in the NBU's macroeconomic forecast on inflation expectations.

\section{CONCLUDING REMARKS}

This work offers our vision of the comprehensive functioning of the MTM and its channels based on the latest studies and the practical experience of implementing monetary policy in Ukraine. Drastic changes in the economic and financial system after the 2014-15 crisis and the recent adoption of the inflation targeting regime make econometric calculations based on the data prior to 2013 irrelevant for an evaluation of monetary transmission channels. However, in cases where high-frequency data is available, an empirical analysis is based on econometric calculations, for example, for the relationship between the key rate and money market rates or commercial bank loan and deposit rates.

The results of this study prove that the MTM channels over which the NBU has a strong influence have been given the opportunity to develop since the adoption of inflation targeting and after the completing of the cleanup of the banking system. In particular, this study finds that the interest rate channel, exchange rate channel, and expectations channel are effective. Other channels are still not influential (the lending channel) or rudimentary (the asset price channel). That is a consequence of the financial system (low stock market development and negligible role of longterm investment institutes like pension funds) and historical factors (high and volatile inflation, low trust in the central bank, structural changes, etc.).

Interest rate channel. Thanks to the implementation of the operational design of monetary policy typical for central banks that pursue inflation targeting, the NBU was able to establish control over short-term interest rates in the interbank market. The magnitude of the pass-through of changes in the key rate to interbank market rates is high and their fluctuations stay within the range for the NBU's overnight standing facilities. These rates quickly and fully affect the short-term end of the yield curve for government securities.

Commercial bank rates on business loans and deposits quickly and fully react to changes in the key rate. The reaction of household deposit rates is slower and weaker. Interest rates on household loans are defined by nonprice factors, since the majority of these loans are short-term consumer loans. Still, the situation may change with the development of mortgage lending. Meanwhile, interest rates on household deposits stopped declining after the NBU began raising its key rate in October 2017. However, the increase has been slow as banks have seen a substantial inflow of hryvnia deposits amid the macroeconomic stabilization, which has reduced competition among banks. At the same time, when the banking system's liquidity declined, competition intensified mostly for corporate funds, which react more quickly to interest rate changes. Nevertheless, we believe the weak effect of the key rate on interest rates for individual deposits is temporary. The arbitrage opportunity between the yield on government securities (not subject to taxation) and interest rates on individual deposits will not remain in the coming years. The announcement by Ukraine's Finance Ministry to simplify access for retail customers to the government securities market should expedite the process.

The effect of interest rate changes on investment and consumption decisions by economic agents is less pronounced in Ukraine than in other countries due to the country's low financial and credit depth. At the same time, considering the limited choice of instruments for household savings where bank deposits play the lead role, commercial bank deposit rates must be a more important element in MTM.

Prospective areas of study. As more data becomes available, the effect of the MTM in Ukraine can be assessed using macro models with added micro analyses of particular transmission chains, first of all, the transition from money market rates to individual banks' interest rates. The effect of interest rate changes on investment and consumption decisions by economic agents remains a topic that has barely been touched in Ukraine, and it deserves an in-depth study.

Credit channel. Some evidence shows that the credit channel's contribution to the MTM is insignificant. The volume of loan supply shows a weak reaction to changes in monetary conditions, because commercial banks are more constrained by other factors in making decisions. Firstly, after the economic and financial crisis of 201415 , commercial banks have preferred to finance reliable borrowers regardless of monetary conditions. Secondly, the faster resumption of bank lending (loan supply) is restrained by institutional factors, especially the poor protection of creditor rights. Thirdly, large corporations (especially exporters) have an alternative to bank lending in the form of borrowing from their parent company and from the sale of Eurobonds.

After bank balance sheets are cleaned from NPLs and other institutional improvements are implemented, we expect greater lending activity of the banking system. That will increase the availability of data, which will make it possible the quantitative assessment of the lending channel.

Prospective areas of study. A study of Ukrainian banks and corporations using large data sets is a prospective area of study. That would allow us to identify factors that affect loan supply other than demand for loans.

Exchange rate channel. The strengthening of the hryvnia exchange rate that started in January 2018 after a number of interest rate hikes offers convincing evidence of the functioning of uncovered interest rate parity.

The effect of the exchange rate on macroeconomic indicators is one of the main means of influencing inflation due to a substantial pass-through effect. According to existing studies, the pass-through is nonlinear: a substantial devaluation of the exchange rate leads to a high passthrough, whereas mild fluctuations do not produce a serious inflationary response. That justifies the use of foreign currency interventions by the NBU to smoothen exchange rate volatility to help achieve the inflation target. 
The effect on economic growth is less pronounced. The negative effect from a stronger exchange rate due to a deterioration of competitiveness is largely offset by positive balance sheet effects because of the high dollarization of the corporate sector's obligations.

Prospective areas of study include the effects of interest rate changes and foreign currency interventions (volumes) on exchange rate changes.

Asset price channel. In Ukraine, the power of the asset price channel is very low. Firstly, the stock market is in a nascent state and stocks play no statistically significant role in the financial assets of households. The same is true of the debt securities market, where only government securities enjoy any true activity. The effectiveness of this channel can strengthen only if (or when) household income and savings increase. Some progress can also be expected once mortgage lending recovers in the future, which would strengthen the power of the asset price channel via the real estate prices.

Expectations channel. An analysis of data on inflation expectations indicates that these expectations are not only influenced by current and backward-looking inflation,

\section{REFERENCES}

Abrahams, M., Adrian, T., Crump, R. K., Moench, E. (2015). Decomposing real and nominal yields curves. Federal Reserve Bank of New York Staff Reports, 570. Federal Reserve Bank of New York. Retrieved from https://www.newyorkfed.org/medialibrary/media/research/ staff_reports/sr570.pdf

Airaudo, M., Buffie, E., Zanna, L.-F. (2016). Inflation targeting and exchange rate management in less developed countries. IMF Working Paper, 2016/55. International Monetary Fund. https://doi.org/10.5089/9781513567433.001

Andries, N., Billon, S. (2016). Retail bank interest rate pass through in the euro area: An empirical survey. Economic Systems, 40(1), 170-194. https://doi.org/10.1016/j. ecosys.2015.06.001

Bailliu, J., Fujii, E. (2004). Exchange rate pass-through and the inflation environment in industrialized countries: An empirical investigation. Bank of Canada Working Paper, 2004-21. Bank of Canada. Retrieved from https://www. bankofcanada.ca/wp-content/uploads/2010/02/wp04-21.pdf

Batini, N., Kuttner, K., Laxton, D. (2005). Does inflation targeting work in emerging markets? In World Economic Outlook (pp. 161-186). International Monetary Fund. Retrieved from https://www.imf.org/external/pubs/ft/weo/2005/02

Bernanke, B. S., Gertler, M. (1995). Inside the black box: The credit channel of monetary policy. Journal of Economic Perspectives, 9, (4), 27-48. https://www.jstor.org/stable/2138389

Chmielewski, T., Kapuściński, M., Kocięcki, A., Łyziak, T., Przystupa, J., Stanisławska, E., Wróbel, E. (2018). Monetary policy transmission mechanism in Poland. What do we know in 2017? NBP Working Papers, 286. Warsaw: Narodowy Bank Polski, Economic Research Department. Retrieved from http://www.nbp.pl/publikacje/materialy_i_studia/286_en.pdf but also by forward-looking inflation. Economic agents are better positioned to make forecasts than to simply use naïve forecasts. That is especially true of professional analysts, who already have a better understanding of the goals and the response function of the NBU's monetary policy. The inflation expectations of firms and households are still loosely anchored to the NBU's targets. That is natural given the initial low degree of trust, short history of inflation targeting, and significant inflationary shocks of the last years.

This study offers reasons to believe that inflation expectations can be anchored close to the NBU's inflation target once the NBU gains more experience in executing a consistent monetary policy aimed at ensuring price stability.

Prospective areas of study. With more data available, especially for the period for which the NBU has targeted inflation, the prospective areas of study may include: assessing the persistency of inflation expectations and the degree to which they stay close to the inflation target; evaluating the period when inflation expectations return to the target value after a sizable price shock; analyzing the effect of changes in the NBU's macroeconomic forecast on inflation expectations.

Coibion, O., Gorodnichenko, Y. (2015). Inflation expectations in Ukraine: A long path to anchoring? Visnyk of the National Bank of Ukraine, 233, 6-23. https://doi.org/10.26531/vnbu2015.233.006

Darvas, Z. (2013). Monetary transmission in three central European economies: evidence from time-varying coefficient vector autoregressions. Empirica, 40 (2), 363-390. https://doi.org/10.1007/s10663-012-9197-4

De Bondt, G., Mojon, B., Valla, N. (2005). Term structure and the sluggishness of retail bank interest rates in euro area countries. Working Paper Series, 518. European Central Bank. Retrieved from https://www.ecb.europa.eu/pub/pdf/ scpwps/ecbwp518.pdf

Demchuk, O., Łyziak, T., Przystupa, J., Sznajderska, A., Wróbel, E. (2012). Monetary policy transmission mechanism in Poland. What do we know in 2011? Working Paper, 116. Warsaw: National Bank of Poland. Retrieved from https://www.nbp.pl/publikacje/materialy_i_studia/116_en.pdf

Égert, B., MacDonald, R. (2008). Monetary transmission mechanism in Central and Eastern Europe: surveying the surveyable. OECD Economics Department Working Papers, 654. OECD. https://doi.org/10.1787/230605773237

European Central Bank. (2009). Recent developments in the retail bank interest rate pass-through in the euro area. ECB Monthly Bulletin, August 2009, 93-105. Retrieved from https://www.ecb.europa.eu/pub/pdf/other/mb200908_ pp93-105en.pdf

Faryna, O. (2016). Nonlinear exchange rate pass-through to domestic prices in Ukraine. Visnyk of the National Bank of Ukraine, 236, 30-42. https://doi.org/10.26531/ vnbu2016.236.030 
Jonsson, T., Österholm, P. (2012). The properties of surveybased inflation expectations in Sweden. Empirical Economics, 42(1), 79-94. https://doi.org/10.1007/s00181-010-0428-x

Kapuściński, M. (2017). The role of bank balance sheets in monetary policy transmission: Evidence from Poland. Eastern European Economics, 55(1), 50-69. https://doi.org/10.1080/00128775.2016.1255559

Kapuściński, M., Kocięcki, A., Kowalczyk, H., Łyziak, T., Przystupa, J., Stanisławska, E., Sznajderska, A., Wróbel. E. (2016). Monetary policy transmission mechanism in Poland. What do we know in 2015? NBP Working Papers, 249. Warsaw: Narodowy Bank Polski, Economic Institute. Retrieved from https://www.nbp.pl/publikacje/materialy_i_ studia/249_en.pdf

Kapuściński, M., Stanisławska, E. (2016). Interest rate pass-through in Poland since the global financial crisis. NBP Working Papers, 247. Warsaw: Narodowy Bank Polski, Economic Institute. Retrieved from https://www.nbp.pl/ publikacje/materialy_i_studia/247_en.pdf

Kara, H., Ogunc, F., Özlale, Ü., Sarikaya, C. (2007). Estimating the output gap in a changing economy. Southern Economic Journal, 74(1), 269-289. https://www.jstor.org/stable/20111963

Kátay, G., Wolf, Z., (2004). Investment behavior, user cost and monetary policy transmission - the case of Hungary. MNB Working Papers, 2004/12. Budapest: Magyar Nemzeti Bank (Central Bank of Hungary). Retrieved from https://www.mnb.hu/letoltes/wp2004-12.pdf

Masson, P. R., Savastano, M. A., Sharma, S. (1997). The scope for inflation targeting in developing countries. IMF Working Paper, WP/97/130. International Monetary Fund. Retrieved from https://www.imf.org/external/pubs/ft/wp/wp97130.pdf

Mishkin, F. S. (1995). Symposium on the monetary transmission mechanism. The Journal of Economic Perspectives, 9(4), 3-10. https://doi.org/10.1257/jep.9.4.3

Nguyen, Ch. V., Phan, Kh. D, Williams, M. (2017). The transmission mechanism of Russian Central Banks countercyclical monetary policy since 2011: Evidence from the interest rate pass-through. Journal of Eastern European and Central Asian Research, 4(2), 1-13. https://doi.org/10.15549/jeecar.v4i2.165

Nordstrom, A., Roger, S., Stone, M., Shimizu, S. Kişinbay, T., Restrepo, J. (2009). The role of the exchange rate in inflation-targeting emerging economies. IMF Occasional Papers, 267. International Monetary Fund. https://doi.org/10.5089/9781589067967.084
Pesaran, M. H., Shin, Y. (1999). An autoregressive distributed lag modelling approach to cointegration analysis. In Econometrics and Economic Theory in the 20th Century: The Ragnar Frisch Centennial Symposium (p. 371-413). Cambridge: Cambridge University Press. https://doi.org/10.1017/cbo9781139052221.011

Pesaran, M. H., Shin, Y., Smith, R. J. (2001). Bounds testing approaches to the analysis of level relationship. Journal of Applied Econometrics, 16(3), 289-326. https://doi.org/10.1002/jae.616

Pham, Th., Talavera, O., Tsapin, A. (2018). Shock contagion, asset quality and lending behavior. NBU Working Paper Series, 01/2018. National Bank of Ukraine. Retrieved from https://bank.gov.ua/doccatalog/document?id=62899125

Ranchhod, S. (2003). The relationship between inflation expectations survey data and inflation. Reserve Bank of New Zealand Bulletin, 66(4), 50-65. Reserve Bank of New Zealand. Retrieved from https://www. rbnz.govt.nz/-/media/ReserveBank/Files/Publications/ Bulletins/2003/2003dec66-4.pdf

Rezessy, A. (2005). Estimating the immediate impact of monetary policy shocks on the exchange rate and other asset prices in Hungary. MNB Occasional Papers, 38. Budapest: Magyar Nemzeti Bank (Central Bank of Hungary). Retrieved from https://www.mnb.hu/letoltes/op-38.pdf

Sharma, N. K., Bicchal, M. (2018). The properties of inflation expectations: Evidence for India. EconomiA, 19(1), 74-89. https://doi.org/10.1016/j.econ.2017.12.002

Shevchuk, V. (2017). The impact of anticipated and unanticipated exchange rate variability in Ukraine. Visnyk of the National Bank of Ukraine, 241, 34-47. https://doi.org/10.26531/vnbu2017.241.033

Stanisławska, E. (2014). Interest rate pass-through in Poland. Evidence from individual bank data. NBP Working Papers, 179. Warsaw: Narodowy Bank Polski, Economic Institute. Retrieved from https://ssl.nbp.pl/publikacje/materialy_i_studia/179_en.pdf

Taylor, J. B. (2000). Low inflation, pass-through, and pricing power of firms. European Economic Review, 44(7), 1389-1408. https://doi.org/10.1016/s0014-2921(00)00037-4

Vonnák, B. (2007). The Hungarian monetary transmission mechanism: an assessment. MNB Working Papers, 2007/3. Budapest: Magyar Nemzeti Bank (Central Bank of Hungary). Retrieved from https://www.mnb.hu/letoltes/wp2007-3.pdf 